\title{
Impact of achondroplasia on Latin American patients: a systematic review and meta-analysis of observational studies
}

Virginia Fano ${ }^{1}$, Chong A. Kim², Pablo Rosselli ${ }^{3}$ Regina El Dib ${ }^{4}$, Renée Shediac ${ }^{5}$, Tatiana Magalhães ${ }^{6}$, Debora Mesojedovas ${ }^{6}$ and Juan Llerena $\mathrm{Jr}^{7^{*}}$ (D)

\begin{abstract}
Background: Achondroplasia (ACH), the most common form of disproportionate short stature, is caused by a pathogenic variant in the fibroblast growth factor receptor 3 gene. Recent advances in drug therapy for ACH have highlighted the importance of elucidating the natural history and socioeconomic burden of this condition. Recognition that there are many potential issues for the patient with $\mathrm{ACH}$ is the first step in planning cost-effective interventions in Latin America (LATAM), a vast geographic territory comprising countries with multicultural characteristics and wide socioeconomic differences. We conducted a systematic literature review to characterize the impact of ACH on affected individuals and on healthcare resources in LATAM countries.
\end{abstract}

Methods: Searches of the global medical literature as well as regional and local medical literature up to August 2020. Observational studies on patients with ACH from any LATAM country. Pairs of reviewers independently screened eligible articles, extracted data from included studies, and assessed their risk of bias.

Results: Fifty-three unique studies (28 case series and cross-sectional studies and 25 case reports) including data on 1604 patients were eligible. Of these studies, 11 had data available for meta-analysis. Both premature mortality and all-cause mortality in the pooled studies was 15\% [95\% Confidence Interval (CI) $1.0 \mathrm{E}-3$ to $0.47 ; \mathrm{I}^{2}=82.9 \%, p=0.0029$; three studies, $n=99$ patients]. Frequency of cardio-respiratory-metabolic disorders was $17 \%[95 \% \mathrm{Cl} 0.04-0.37$; $\mathrm{I}^{2}=90.3 \%, p<0.0001$; four studies, $\mathrm{n}=230$ patients]; nervous system disorders was $18 \%\left[95 \% \mathrm{Cl} 0.07-0.33 ;\left.\right|^{2}=84.6 \%\right.$, $p<0.0001$; six studies, $\mathrm{n}=262$ patients]; ear, nose, throat and speech disorders was $32 \%$ [95\% Cl $0.18-0.48 ; I^{2}=73.4 \%$, $p=0.0046$; five studies, $\mathrm{n}=183$ patients]; and spinal issues including stenosis, compression and associated pain was $24 \%\left[95 \% \mathrm{Cl} 0.07-0.47 ;\left.\right|^{2}=91.3 \%, p<0.0001\right.$; five studies, $\mathrm{n}=235$ patients].

Conclusions: There is currently evidence of high clinical burden in ACH patients in LATAM countries. Establishing the impact of ACH provides the necessary foundation for planning tailored and effective public health interventions.

Keywords: Achondroplasia, Skeletal dysplasia, Latin America

*Correspondence: juan.Ilerena@iff.fiocruz.br

${ }^{7}$ Instituto Nacional Fernandes Figueira (IFF), Fundação Osvaldo Cruz, Av. Rui Barbosa 716, Rio de Janeiro, RJ 22250 020, Brazil

Full list of author information is available at the end of the article

\section{Background}

Achondroplasia $(\mathrm{ACH})$ is the most prevalent skeletal dysplasia, occuring with a frequency of 1 in 25,000 births [1-3], with a worldwide birth prevalence estimated to be 4.6 per 100,000 [4]. In Latin American (LATAM) countries, the birth prevalence ranges from $0.26[4,5]$ to approximately $0.45[6,7]$ in 10,000 . original author(s) and the source, provide a link to the Creative Commons licence, and indicate if changes were made. The images or other third party material in this article are included in the article's Creative Commons licence, unless indicated otherwise in a credit line to the material. If material is not included in the article's Creative Commons licence and your intended use is not permitted by statutory regulation or exceeds the permitted use, you will need to obtain permission directly from the copyright holder. To view a copy of this licence, visit http://creativecommons.org/licenses/by/4.0/. The Creative Commons Public Domain Dedication waiver (http://creativeco mmons.org/publicdomain/zero/1.0/) applies to the data made available in this article, unless otherwise stated in a credit line to the data. 
However, data from the Latin American Collaborative Study of Congenital Malformations (ECLAMC) estimates a similar incidence in non-LATAM countries of 0.43 in 10,000 or 0.45 in 10,000 [8]

In LATAM countries, $\mathrm{ACH}$ is often assumed to be compatible with a healthy and productive life. However, current evidence indicates that $\mathrm{ACH}$ is associated with a range of medical complications including obstructive sleep apnea, spinal stenosis, chronic pain, and cervicomedullary compression with subsequent risk of high surgical burden and death $[9,10]$. In addition, $\mathrm{ACH}$ patients may experience a number of socioeconomic issues such as social isolation, lower self-esteem, less education, and lack of employment opportunities [11-15]. Management of all these complications can be challenging as it requires multidisplinary intervention.

Recognition that there are many potential issues for the patient with $\mathrm{ACH}$ is the first step in planning costeffective interventions in LATAM, a vast geographic territory comprising countries with distinct cultures, socioeconomic structures, and public healthcare systems. However, due to the paucity of published studies on LATAM patients with $\mathrm{ACH}$, particularly in the English-language medical literature, there is currently limited understanding of the impact of $\mathrm{ACH}$ on affected individuals and on healthcare systems in this region of the world. Moreover, of the published studies, the majority have stemmed from single centres with small patient cohorts. Furthermore, despite the growing evidence in the English-language medical literature of the clinical and psychosocial burden among patients with $\mathrm{ACH}$, published studies are not exclusively based on LATAM populations and therefore the findings may not necessarily be generalizable to LATAM patients, and the experiences of living with $\mathrm{ACH}$ may not be the same across different regions of the world. We therefore conducted a systematic literature review and metaanalysis to better specifically characterize the impact of ACH in LATAM countries at the level of patientimportant outcomes as well as at the economic (socioeconomic, healthcare utilization) level.

\section{Materials and methods}

Our review followed recommendations for systematic reviews and meta-analyses (PRISMA) [16] of observational studies in epidemiology (MOOSE) [17] statements. This systematic review was registered in the PROSPERO (International Prospective Register of Systematic Reviews) database under the number CRD42020204963.

\section{Eligibility criteria}

We included any epidemiological observational study (e.g., cohort, case-control, nested case-control, crosssectional studies, prospective case series, case report) on patients with ACH from any LATAM country (e.g., Brazil, Argentina, Colombia, Mexico, Costa Rica, Peru), regardless of whether they reported our pre-defined patient-important outcomes and/or economic burden outcomes defined below. A diagnosis of $\mathrm{ACH}$ in patients in the included studies was based on genetic confirmation and/or clinical diagnosis of $\mathrm{ACH}$ (clinical examination and/or radiological assessment).

We excluded studies that evaluated patients with only hypochondroplasia as well as commentaries, reviews, off-topic studies, and those with co-occurrence of $\mathrm{ACH}$ and another syndrome.

For patient-important outcomes, we were interested in investigating the following:

- Mortality:

- Premature mortality defined as sudden death within 1 year of age;

- All-cause mortality; and

- Cardiovascular mortality.

- Physical comorbidities:

- Cardio-respiratory-metabolic disorders (e.g., cardiovascular diseases, obstructive sleep apnea, obesity).

- Nervous system disorders (e.g., cervicomedullary compression, gross motor delay);

- Ear, nose, throat and speech disorders (e.g., otitis media, hearing loss, upper airway obstruction, speech delay);

- Spinal issues including stenosis, compression and associated pain (e.g., chronic back pain, symptomatic spinal stenosis, thoracolumbar kyphosis, lumbar hyperlordosis);

- Orthopedic complications (e.g., chronic leg pain, wheelchair bound, limited elbow extension);

- Pain;

- Perinatal complications (e.g., premature birth, hospitalization); and

- Others (e.g., hypothyroidism, difficulty in performing epidural anesthesia for cesarean delivery, tumours, blood transfusion, length of hospitalization).

- Humanistic: 
- Psychosocial disorders: depression, anxiety, bullying, isolation, hopelessness, somatization, humiliation, stigma, perception about their psychosocial life, etc., measured by non-validated and validated questionnaires as defined by the included studies;

- Delayed self-care skills (e.g., toileting, cup-drinking);

- Suicide attempts, and/or suicide rates; and

- Social adaptation challenges;

- Impact of the disease on patient and/or caregiver health-related quality of life, activities of daily living, work productivity, education, employment, social, and so forth; and

- Quality of life measured by non-validated and validated questionnaires, as defined by the included studies, such as the Brief Pain Inventory-Short Form (BPI-SF) Questionnaire, the Quality of Life Short Stature Youth (QoLiSSY) Questionnaire, and the Pediatric Quality of Life Inventory (PedsQL).

At the economic level, we were interested in investigating the following outcomes:

- Socioeconomic burden (e.g., securing employment) measured by non-validated and validated questionnaires, as defined by the included studies such as the Work and Productivity and Activity Impairment (WPAI-SHP).

- Environmental burden:

- Lack of equipment, furniture, toys, shoes, etc., matching anthropometric limitations;

- Limitation of physical access to transportation modalities;

- Adaptation to standard transport equipment and; - Challenges in physical activity.

- Health economic impact:

- Direct and/or indirect costs, treatment costs, health care resource use, cost of comedications, hospitalizations.

\section{Data source and searches}

Using Medical Subject Headings (MeSH) based on the terms "achondroplasia" and "skeletal dysplasia" (Additional file 1: Table S1) we performed the search in the global medical literature using the Medical Literature Analysis and Retrieval System Online (MEDLINE, via PubMed, from 1946 to August 2020), Excerpta Medica Database (EMBASE, via Elsevier, from 1974 to August 2020), Cochrane Central Register of Controlled Trials
(CENTRAL, via Wiley, issue 8, 2020), and Web of Science (to August 2020).

We also conducted the search using both Spanish and English terms in the regional and local medical literature using Latin American and Caribbean Health Sciences Literature (LILACS, 1982 to August 2020), Scientific Electronic Library Online (SciELO, 1997 to August 2020), SciVerse Scopus via Elsevier (to August 2020), the Spanish Bibliographic Index of the Health Sciences (IBECS, 1983 to August 2020), National Bibliography in Health Sciences Argentina (BINACIS, to August 2020), Caribbean Health Sciences Literature (MedCarib, to August 2020), National Medical Sciences Information Center of Cuba (CUMED, to August 2020), and the Brazilian Bibliography of Dentistry (BBO to August 2020). The date of the last search was August 18, 2020.

We also searched the gray literature including ProQuest Dissertations \& Theses Global (1989 to 2020), the National Health Surveillance Agency (ANVISA), Brazilian Digital Library of Theses and Dissertations (BDTD), Latindex Redalyc Latam, Mexico National Institute of Pediatrics website, and conference proceedings. In addition, reference lists of relevant primary studies were hand searched and experts in the field were contacted to obtain additional unpublished data.

We did not impose any language or year restrictions. The search strategy was adapted for each database to achieve more sensitivity. Duplicate records across databases were removed.

\section{Selection of studies}

Reviewers independently screened all titles and abstracts identified by the literature search using online software Covidence (https://www.covidence.org), obtained full-texts articles of all potentially relevant studies, and evaluated them against the eligibility criteria. Reviewers resolved disagreements by discussion or, if necessary, with third party adjudication. We also considered studies reported as abstracts; however, those that did not contain data to extract were excluded from the review. We recorded the selection process and completed a PRISMA (Preferred Reporting Items for Systematic Reviews and Meta-Analyses) flow diagram (Fig. 1).

\section{Data extraction}

Reviewers independently extracted the following data using a pre-standardized data extraction form: (1) first author and year of publication; (2) country; (3) study design; (4) scenario; (5) age, gender, and body mass index (BMI); (6) number of patients; (7) eligibility criteria; and (8) patient-important and economic outcomes, if available. We avoided double counting of participants where there were multiple publications in 


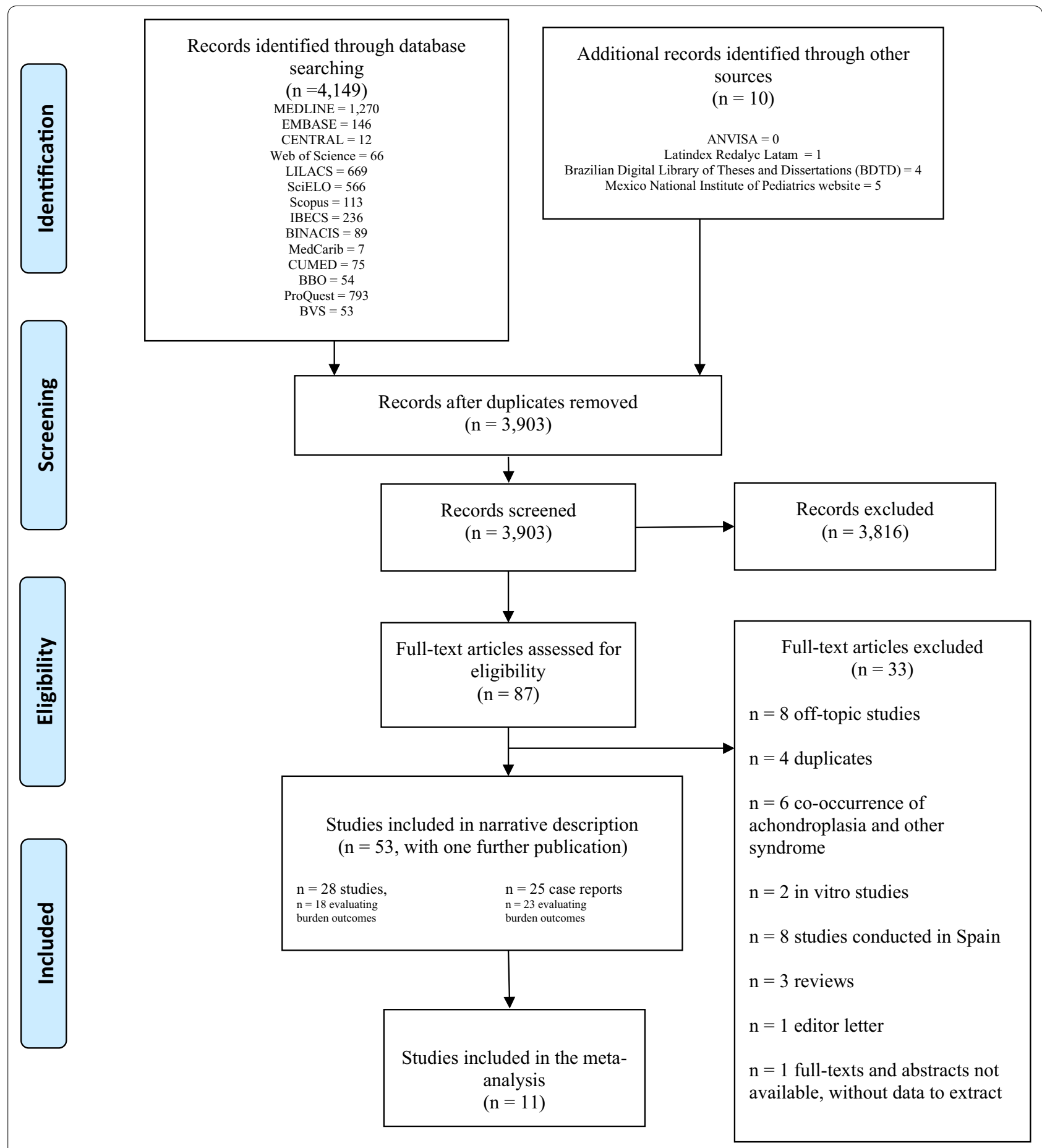

Fig. 1 Search and selection of studies

the same population. If there was more than one published report of the same group of patients, the articles were analysed to verify whether they reported different outcomes. If they presented the same outcomes, we extracted the data from the most complete article. For studies that did not report BMI but provided height and weight we calculated this variable. 


\section{Risk of bias assessment}

For cohort and case-control studies, we planned to assess risk of bias with a modified version of the Ottawa-Newcastle instrument [18] that includes confidence in assessment of exposure and outcome; however, there was no included study classified as either cohort or case-control study.

For cross-sectional studies, we assessed risk of bias with the AXIS tool [19], though we excluded some domains not applied to our review. For case series and case reports, we used the single tool from the Joanna Briggs Institute (JBI) critical appraisal checklist for case reports [20]. However, in our view, the structure of the response options in both AXIS and JBI instruments leaves much to be desired. Therefore, we modified the response options to "definitely yes" (low risk of bias), "partially yes" (not all information needed available), "unclear" (no information to judge), and "definitely no" (high risk of bias), and applied it to our form for risk of bias in both cross-sectional and case series studies.

\section{Data synthesis and statistical analysis}

We performed a systematic review of clinical studies with pooled analysis of proportions [21, 22], using the method of Stuart-Ord (inverse double arcsine square root).

Only case series and cross-sectional studies were considered for any quantitative analysis; case reports were excluded. We analyzed all outcomes as dichotomous variables with their respective confidence intervals (CI) of 95\%. Since we expected that there were both clinical and methodological differences among the included studies, a random-effects model [23] was used to perform the pooled analysis of proportions. A statistically significant difference between two interventions required that their combined 95\% CIs did not overlap [21, 22]. We calculated weighted mean and pooled measure of variability (standard deviation) for quality of life in the Cervan et al., 2008 [24] study as this study presented data of quality of life (QoL) for physical, psychological, social, environmental domains. The meta-analysis was performed with the StatsDirect software, version 2.8.0. (StatsDirect Ltd, Altrincham, Cheshire, UK).

Because of the very sparse data on this rare condition, when there was more than one report of the same type of burden outcome in the same study, we obtained the mean or median value from the subtype of outcome for the proportional meta-analysis to avoid selection bias. For example, on cardio-respiratory-metabolic disorders outcome, one study could report excessive snoring (number of events per number of total patients, 1/39), obesity $(4 / 39)$, adenotonsillectomy (5/39), sleep disturbance (21/39), as well as sleep apnea (39/39). In this example, the median value used would be adenotonsillectomy $(5 / 39)$.

\section{Subgroup and sensitivity analyses}

We planned to perform subgroup analyses if there was a minimum of two studies in each category: (1) LATAM countries (e.g., Brazil versus Argentina); (2) adults versus children; however, there was an insufficient number of studies to allow for these assessments.

We performed a sensitivity analysis to explore causes of heterogeneity of the results, excluding studies according to study designs (i.e., case series versus cross-sectional studies).

\section{Heterogeneity assessment and publication bias}

We investigated heterogeneity using the chi-square test and the $\mathrm{I}^{2}$ statistic [25]. An $\mathrm{I}^{2}$ value of $0-40 \%, 30-60 \%$, $50-90 \%$ or $75-100 \%$ was interpreted as not important, moderate, substantial or considerable heterogeneity, respectively, and significance was assumed when $\mathrm{I}^{2}$ was $>$ than $50 \%$ with a $p<0.1$.

There was an insufficient number of studies (at least 10 or more) to allow for assessment of publication bias through visual inspection of funnel plots.

\section{Results}

\section{Study selection}

Our initial searches identified 4,149 citations. All were from electronic databases, except for ten studies identified through grey literature. After we removed duplicates from different databases, we retained 3,903 potentially relevant articles for further assessment. After reading titles and abstracts, 87 articles were retrieved as full text for further assessment. After screening the full texts, we included 53 clinical studies with one further publication. We excluded 32 studies after reviewing the full papers. The reasons for exclusion are listed in the PRISMA flow diagram (Fig. 1). The total number of included studies is 53 with one further publication, and from these 11 contributed to meta-analysis.

Eight of the included studies were published only as an abstract [26-33], and five studies as theses [34-38]. The remainder of the included studies $(n=40)$ was published as full-text articles [5, 6, 24, 39-74]. One study [75] was published as full-text with an additional publication in abstract format [76]. When information regarding risk of bias or other aspects of methods was unavailable, we attempted to contact study authors for additional information.

\section{Study characteristics}

Tables 1 and 2 summarize the key characteristics from those studies that reported at least one patient-important or economic outcome. Regarding study design, four were case series [26, 34, 35, 73], 24 cross-sectional studies [5, $6,24,29,36-38,40,45,48,50-54,56,58,60,61,66,69$, 


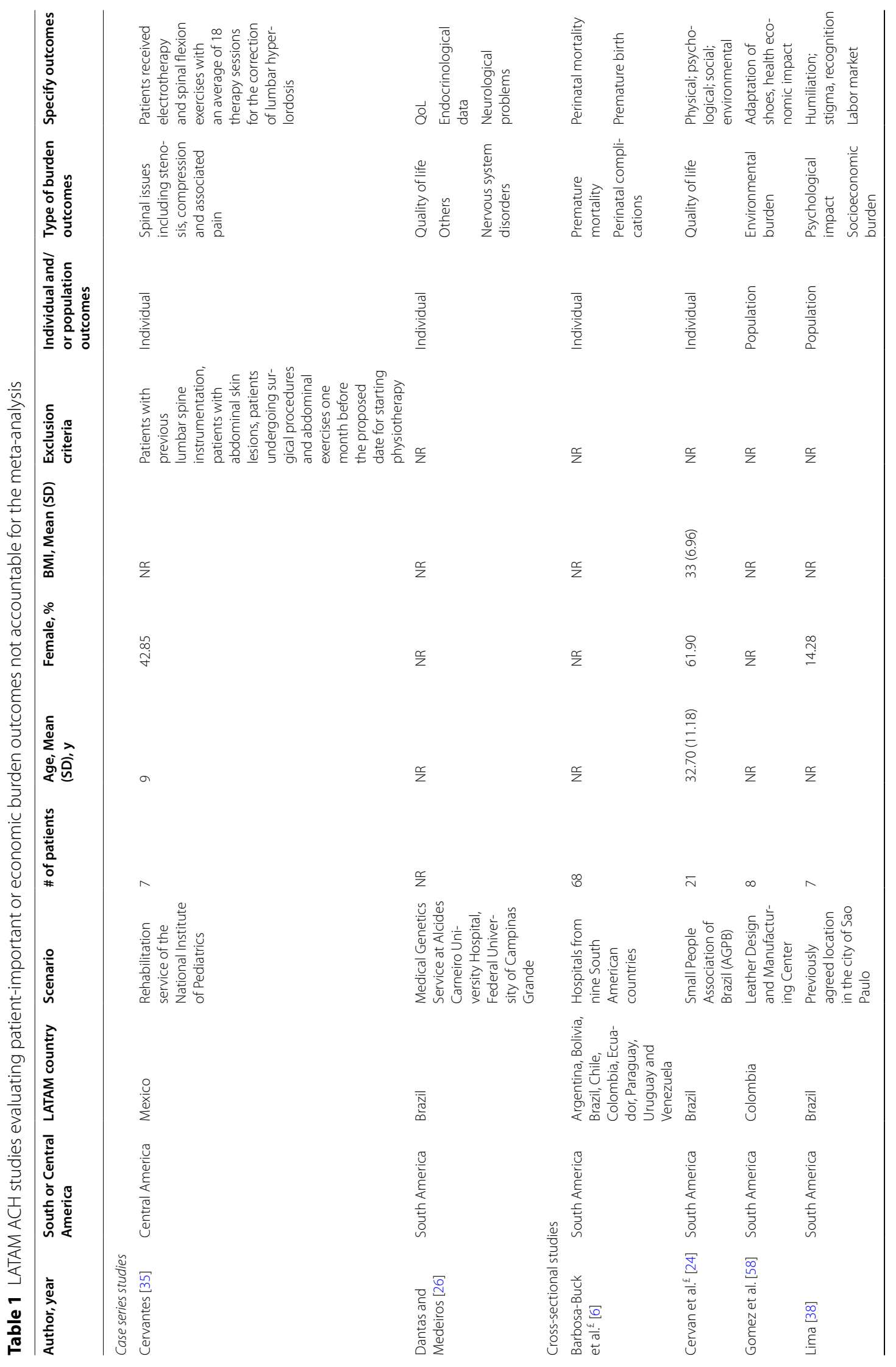




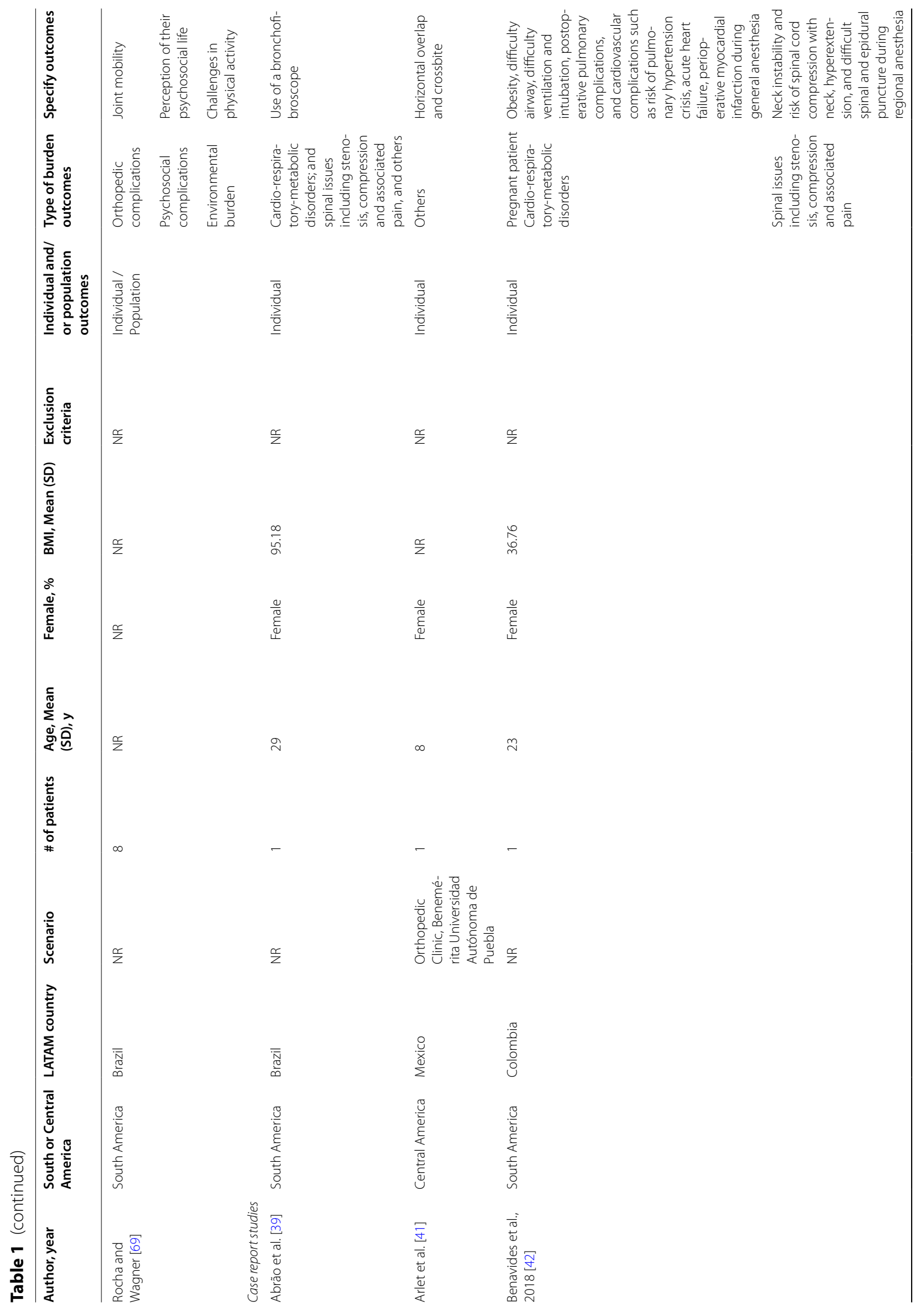




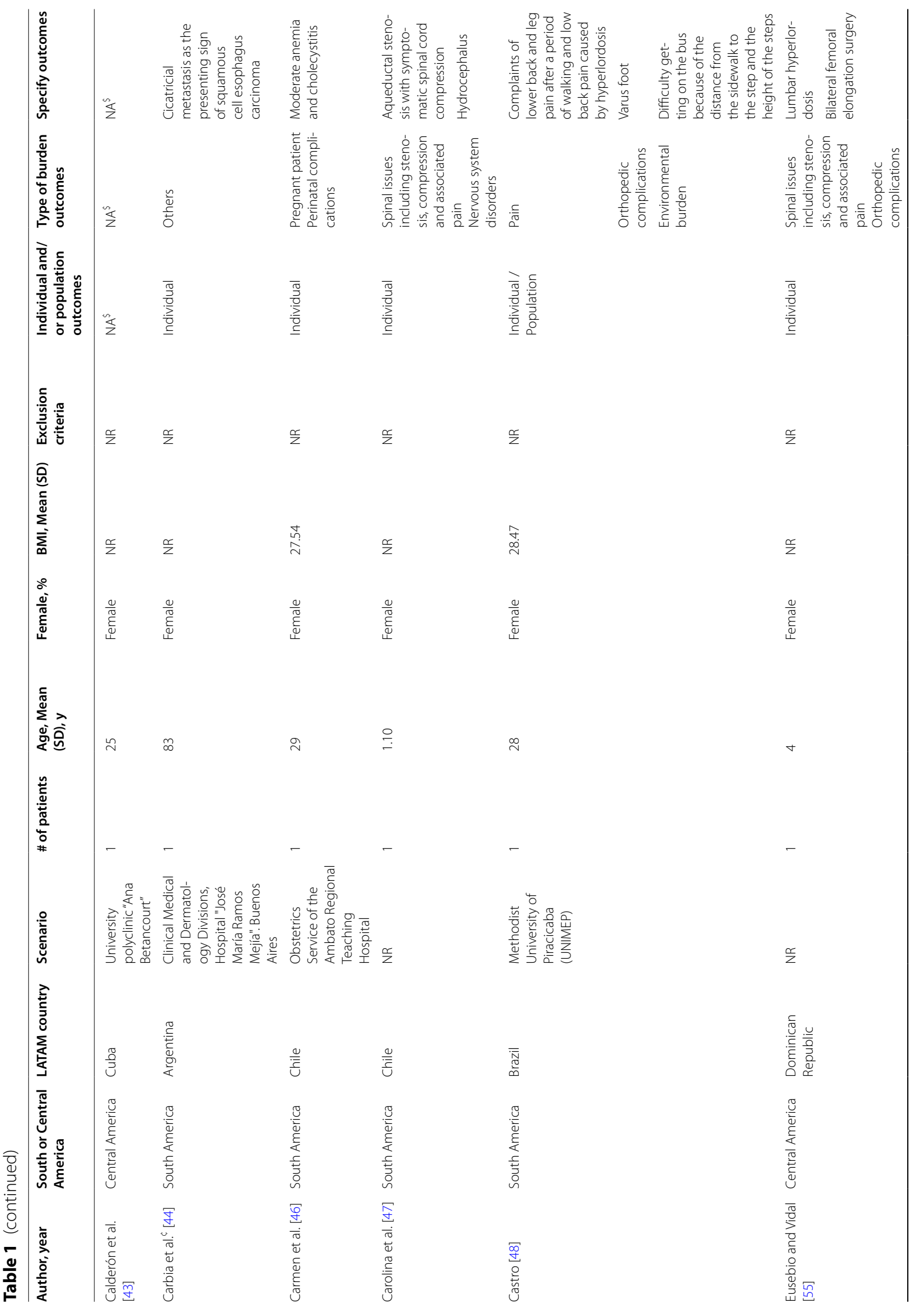




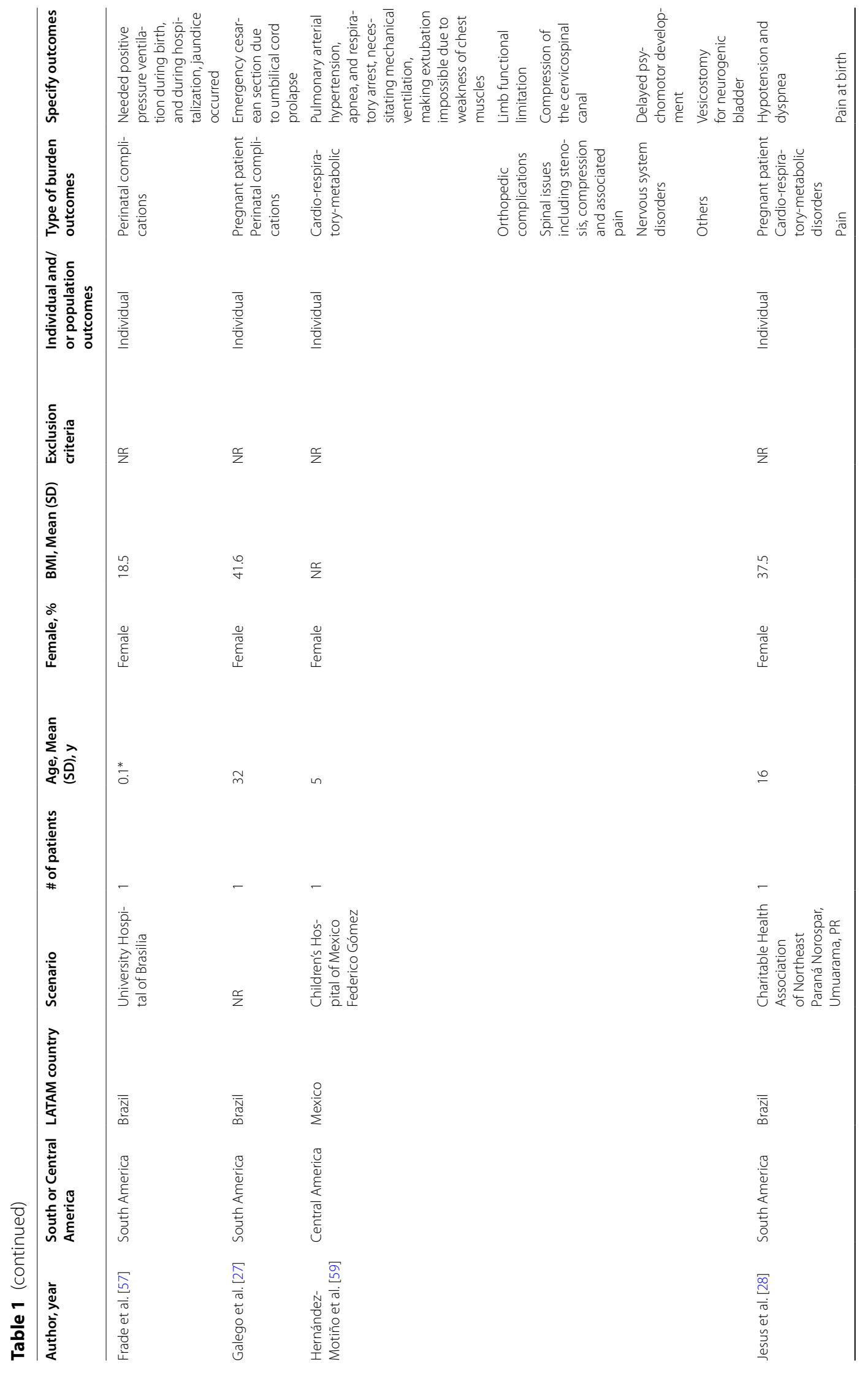




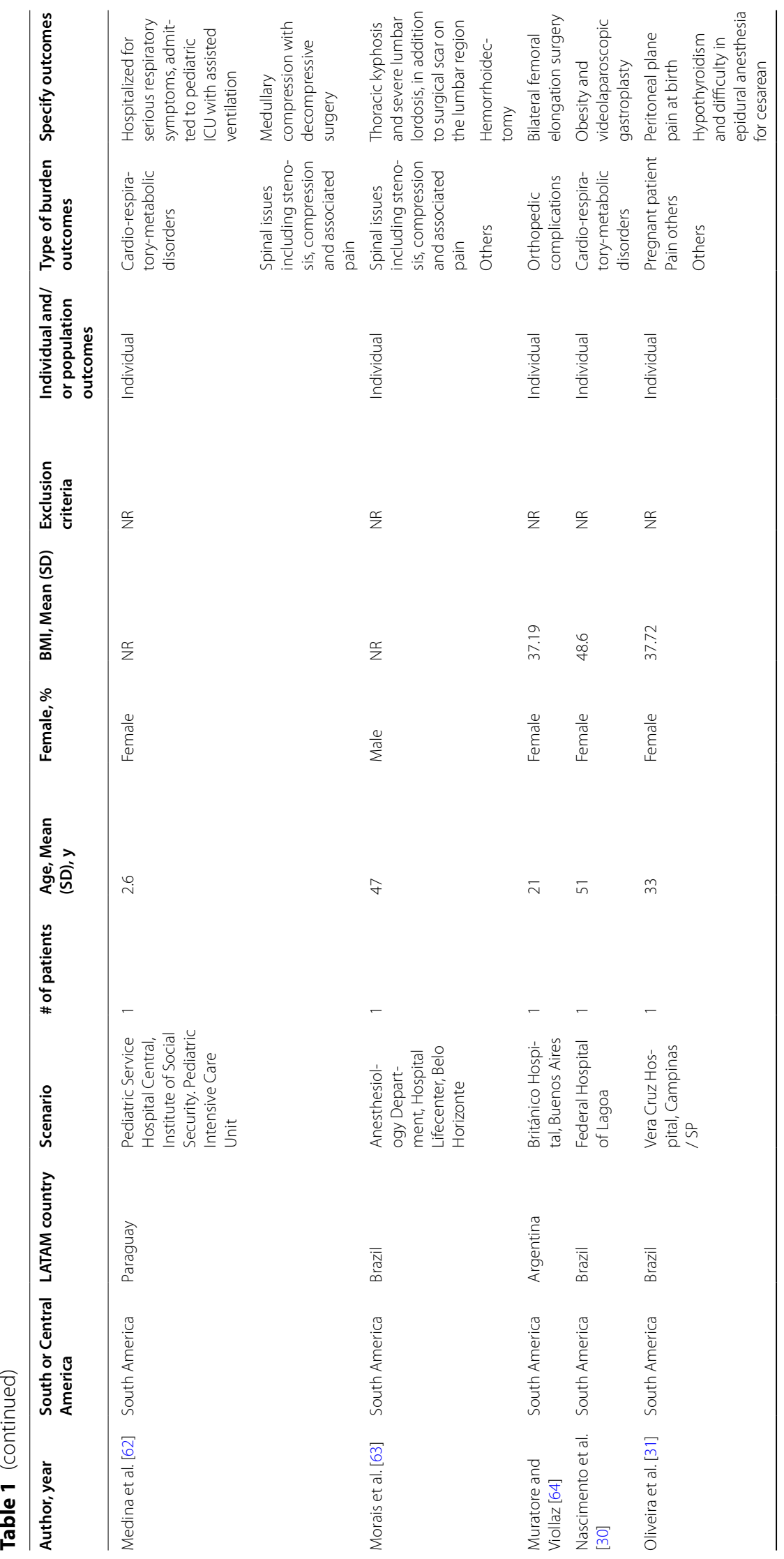




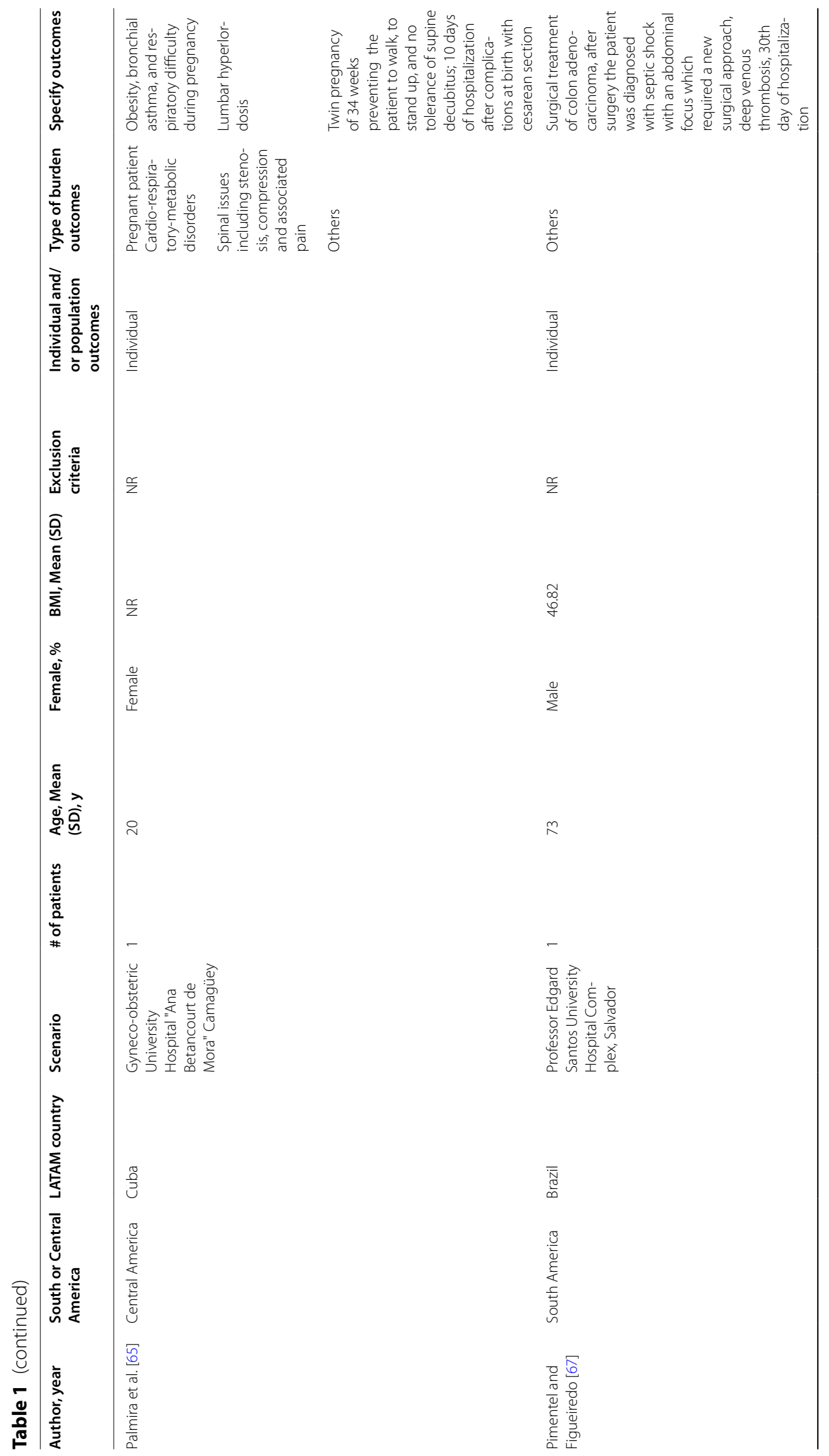




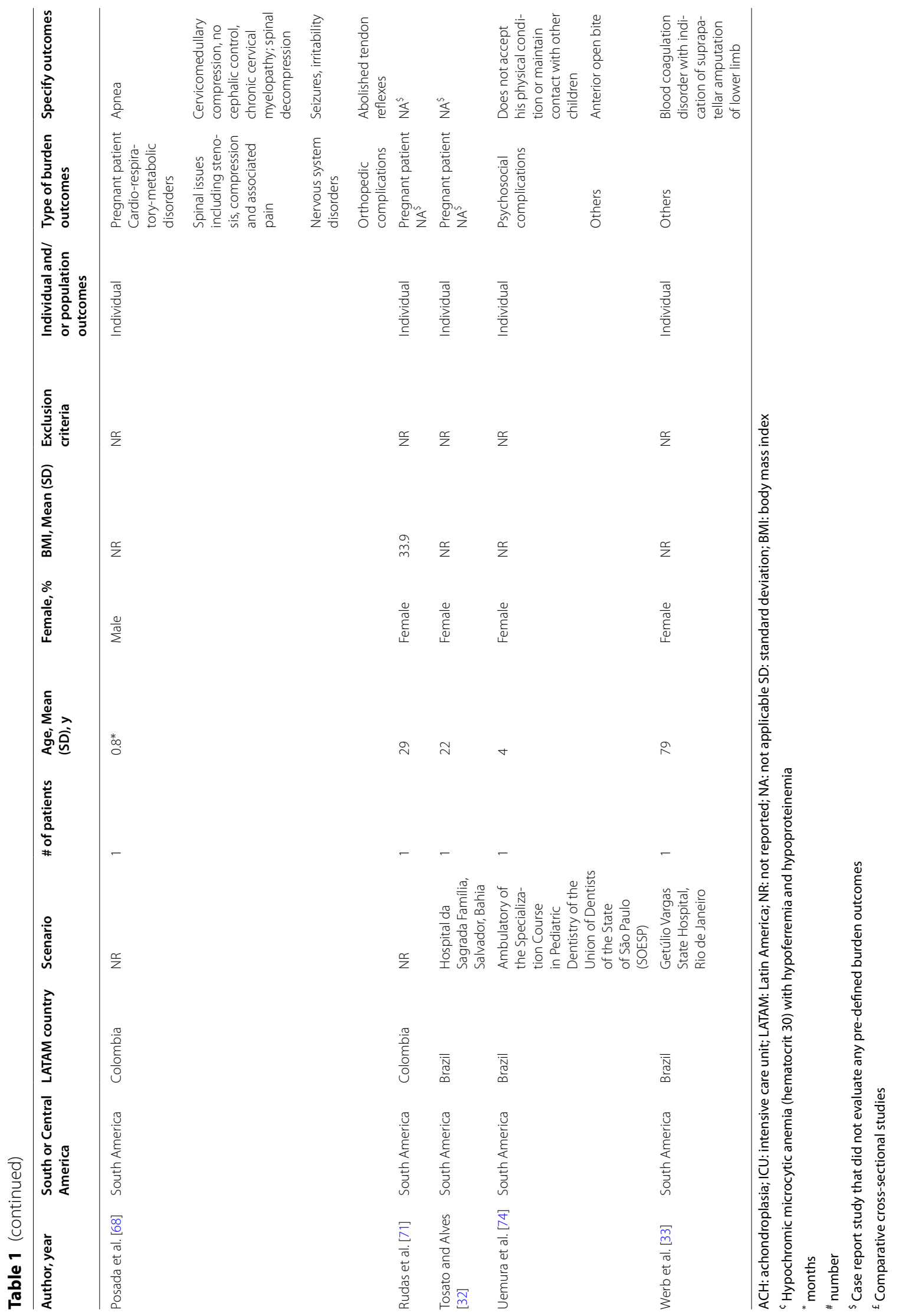


$70,72,75]$, and 25 case reports $[27,28,30-33,39,41-44$, $46,47,49,55,57,59,62-65,67,68,71,74]$.

Twenty-four of the included studies were conducted in Brazil [5, 24, 26-34, 36, 38-40, 45, 49, 57, 63, 66, 67, 69, 74, 75], nine in Argentina [44, 50-54, 56, 64, 73], five in Colombia [42, 48, 58, 68, 71], four in Mexico [35, 37, 41, 59], three in Chile [46, 47, 61], three in Cuba [43, 60, 65], one each in Dominican Republic [55], in Paraguay [62], in Venezuela [72], and in Puerto Rico [70]. Only one article [6] was a multicenter cross-sectional study, which involved nine countries (i.e., Argentina, Bolivia, Brazil, Chile, Colombia, Ecuador, Paraguay, Uruguay, and Venezuela) [6]. Sample sizes from these studies ranged from four [61] to 357 patients [53]. Study participants ranged in age, from a mean age of 3.07 [56] to 40.24 [40] years (Tables 1 and 2).

The type of burden outcome most frequently reported among the cross-sectional and case series studies was nervous system disorders $(28.66 \%, \mathrm{n}=8)$ [5, 29, 34, 37, $56,70,72,73]$, followed by spinal issues including stenosis, compression and associated pain $(25.00 \%, \mathrm{n}=7)$ $[34,35,37,40,56,70,73]$, and then ear, nose, throat and speech disorders $(21.42 \%, \mathrm{n}=6)$ [5, 37, 40, 56, 70, 75]. The majority of the cross-sectional, case series, and case reports studies $(86.36 \%, \mathrm{n}=38)$ reported only on patientimportant outcomes (Tables 1 and 2).

Additional file 2: Table S2 describes study characteristics related to LATAM countries only from those that reported other than patient-important or economic outcome. Ten studies $[36,45,48,50-54,60,61]$ evaluated in addition to burden outcomes, such factors as mutations in the fibroblast growth factor receptor 3 gene [48, 61]; growth velocity [52, 54]; and body proportions references [53].

Additional file 3: Table S3 describes the burden outcomes on 25 LATAM case reports studies. With regards the case reports studies, the majority $(68.0 \%, \mathrm{n}=17)$ $[27,28,30,39,42,44,46,47,49,55,57,59,62-65,68]$ assessed some physical comorbidities such as apnea [59, 68], lower back and leg pain [49], and obesity [65]. Ten case report studies evaluated other outcomes such as hemorrhoidectomy [63] and vesicostomy for neurogenic bladder [59]. Only one study [49] reported on environmental burden (i.e., difficulty getting on the bus because of the distance from the sidewalk to the step and the height of the steps).

\section{Risk of bias assessment}

Figure 2 and Additional files 4, 5: Tables S4 and S5 describe the risk of bias assessment. In the cross-sectional studies (Fig. 2, panel A), at least one of the following domains of sample size, statistical significance, statistics methods, or demographic data were rated as "high risk of bias" in 13 studies (54.16\%) [5, 24, 29, 37, 38, $40,56,58,66,69,70,72,75]$. In the case series studies (Fig. 2, panel B), only two domains (i.e., clear description of both patient's history and post-intervention clinical condition) were rated as "high risk of bias" in three studies $(75.00 \%)[34,35,73]$.

\section{Outcomes}

The results were pooled from studies that reported available data. Therefore, out of 54 included studies $[5,6,24$, 26-76], only 11 [5, 29, 34, 37, 40, 56, 66, 70, 72, 73, 75, 76] were used for the quantitative analysis described below as they presented available data (Table 2).

\section{Mortality}

The pooled proportion for mortality (i.e., sudden death [37] and death due to respiratory complications [56, 72]) was $15 \%$ [ $95 \%$ CI $1.0 \mathrm{E}-3$ to 0.47 ; $\mathrm{I} 2=82.9 \%, p=0.0029$ ] from three studies $[37,56,72]$ with a total of 99 patients (Fig. 3). There was significant statistical heterogeneity in the analyses.

\section{Cardio-respiratory-metabolic disorders}

The pooled proportion for cardio-respiratory-metabolic disorders was $17 \%$ [ $95 \%$ CI 0.04 to 0.37 ; $\mathrm{I} 2=90.3 \%$, $p<0.0001]$ from four studies $[5,37,56,75,76]$ with a total of 230 patients (Fig. 3). There was significant statistical heterogeneity in the analyses. The outcomes used to calculate the mean or median of the cardio-respiratorymetabolic disorders among the studies included in the analysis were: adenotonsillectomy [5]; apnea followed by death [37]; pneumonia [56]; apnea index slightly and moderately increased [75]; desaturations during sleep [75]; and apnea [75]. There was no outcome directly related to cardiac to be included in this category.

\section{Nervous system disorders}

The pooled proportion for nervous system disorders was $18 \%$ [ $95 \%$ CI 0.07 to 0.33 ; I2 $=84.6 \%, p<0.0001$ ] from six studies [5, 29, 37, 56, 72, 73] with a total of 262 patients (Fig. 3). There was significant statistical heterogeneity in the analyses. A sensitivity analysis excluding case series studies from the cross-sectional studies yielded results that were consistent with the primary analysis of $27 \%$ [ $95 \%$ CI 0.09 to 0,50 ; $\mathrm{I} 2=87.2 \%, p<0.0001$ ] from five studies [5, 29, 37, 56, 72] with a total of 165 patients (Fig. 4). There was no statistically significant difference between the primary analysis (i.e., all the studies) and the sensitivity analysis (i.e., only cross-sectional studies), as their CIs overlapped. The outcomes used to calculate the 
mean or median of the nervous system disorders among the studies included in the analysis were: hydrocephalus [5, 37]; convulsive crises [72]; epilepsy [5]; paresthesias and paresias [37]; hypotonia [37]; neurological manifestations [56]; decompressive surgery of foramen magnum [56]; mental retardation [72]; and neurological problems [73].

\section{Ear, nose, throat and speech disorders}

The pooled proportion for ear, nose, throat and speech disorders was $32 \%$ [95\% CI 0.18 to 0.48 ; $\mathrm{I} 2=73.4 \%, p=0.0046]$ from five studies $[5,37,40,56$, $75,76]$ with a total of 183 patients (Fig. 3). There was significant statistical heterogeneity in the analyses. The outcomes used to calculate the mean or median of the ear, nose, throat and speech disorders among the studies included in the analysis were: hearing loss $[5,56,75]$; recurrent otitis media $[37,56,75]$; required surgical treatment (i.e., placement of ventilation tubes) [37]; delay in speech development [56]; hypotonia [56]; hypertrophy of adenoids [75]; snoring; tonsillectomy; and thickening of the tympanic membrane [75].

\section{Spinal issues including stenosis, compression and associated pain}

The pooled proportion for spinal issues including stenosis, compression and associated pain was $24 \%$ [95\% CI 0.07 to 0.47 ; $2=91.3 \%, p<0.0001$ ] from five studies [34, $37,40,56,73$ ] with a total of 235 patients (Fig. 3). There was significant statistical heterogeneity in the analyses. A sensitivity analysis excluding case series studies from the cross-sectional studies yielded results that were consistent with the primary analysis of $17 \%$ [95\% CI 0.01 to 0.45 ; $\mathrm{I} 2=93.4 \%, p<0.0001]$ from three studies $[37,40,56]$ with a total of 194 patients (Fig. 4). There was no statistically significant difference between the primary analysis (i.e., all the studies) and the sensitivity analysis (i.e., only crosssectional studies), as their CIs overlapped. The outcomes used to calculate the mean or median of the spinal disorders among the studies included in the analysis were: osteopenia or osteoporosis [40]; posterior laminectomy [37]; craniocervical compression [34, 37, 56, 73]; spinal compression requiring laminectomy [56]; spinal cord liberation alone [73]; anterior arthrodesis plus posterior instrumented arthrodesis [73]; anterior arthrodesis, associated with fibular grafting followed by posterior simple arthrodesis [73]; posterior arthrodesis instrumented with pedicular screws [73].

\section{Psychosocial disorders}

The pooled proportion for psychosocial complications was $19 \%$ [ $95 \%$ CI 0.02 to 0.48 ; I $=80.8 \%, p=0.0054$ ] from three studies $[5,66,70]$ with a total of 66 patients (Fig. 3). There was significant statistical heterogeneity in the analyses. The outcomes used to calculate the mean or median of the psychosocial disorders among the studies included in the analysis were: depression [5], perception of their body image [66], and mild somatization [70].

\section{Descriptive analysis}

Four studies [38, 58, 69, 75, 76] reported on economic burden outcomes. Gomez et al., 2017 [58] reported on the adaptation of shoes for the $\mathrm{ACH}$ patients and the costs associated with the anthropometric and baropodometric analyses of the foot. This study addressed the design of a footwear system that fulfills form, function and usage of eight persons with $\mathrm{ACH}$ patients. The most relevant information was that footwear should have a low heel (about $2 \mathrm{~cm}$ ) as there is a greater risk of falling due to the instability associated with wearing higher heels (7 $1 / 2 \mathrm{~cm}$ and above), considering the lower center of gravity for $\mathrm{ACH}$ patients; however, patients want to have comfort and elegant heels and shoes (Table 1).

The Lima, 2019 [38] study sought to identify the consequences of stigmatization on social life, including work. The results indicate that people with $\mathrm{ACH}$ experience humiliation and disrespect due to associations made with the stereotype built about them. The authors found this stereotype is commonly used by comedians for entertainment purposes (Table 1).

Medeiros et al., 2017; Medeiros et al., 2019 [75, 76] and Rocha \& Wagner, 2018 [69] describe the challenges associated with physical activities (Table 1). Patients reported that while physical activities can be difficult to perform $[75,76]$, though the regular practice of physical activity improves their self-esteem and confidence which in turn contributes to their sense of social inclusion [69].

None of the included studies reported on the following patient-important outcomes: suicide attempts, and suicide rates; impact of the disease on caregivers, such as health-related quality of life, activities of daily living, work productivity, education, employment, social, and so forth; and social adaptation challenges. Furthermore, none of the included studies reported on the following economic burden outcomes: limitation of physical access to transportation modalities; and adaptation to standard transport equipment.

\section{Discussion \\ Main findings}

Based on pooled data from 11 clinical studies [5, 29, 34, $37,40,56,66,70,72,73,75,76]$ with 409 participants, we 


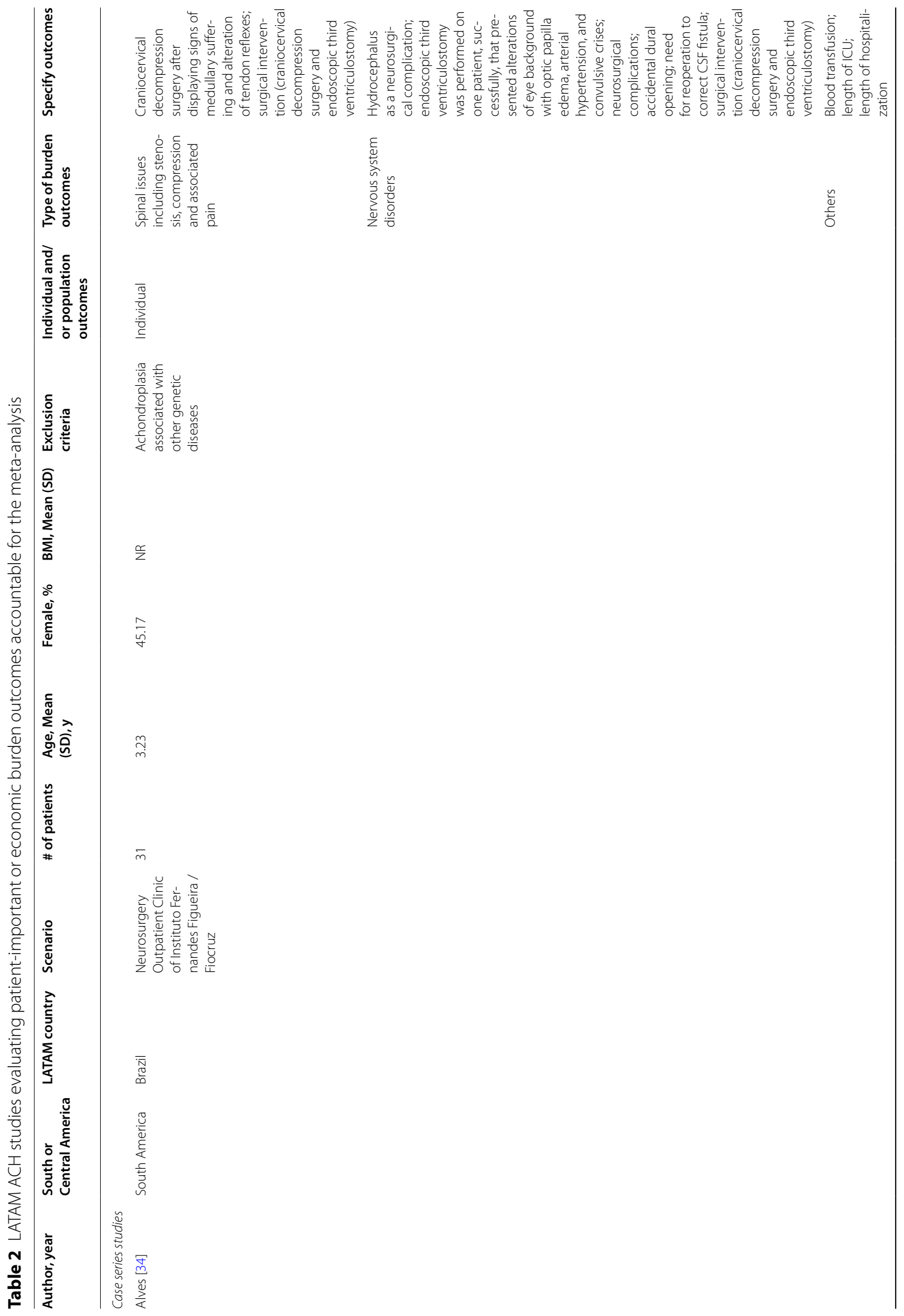




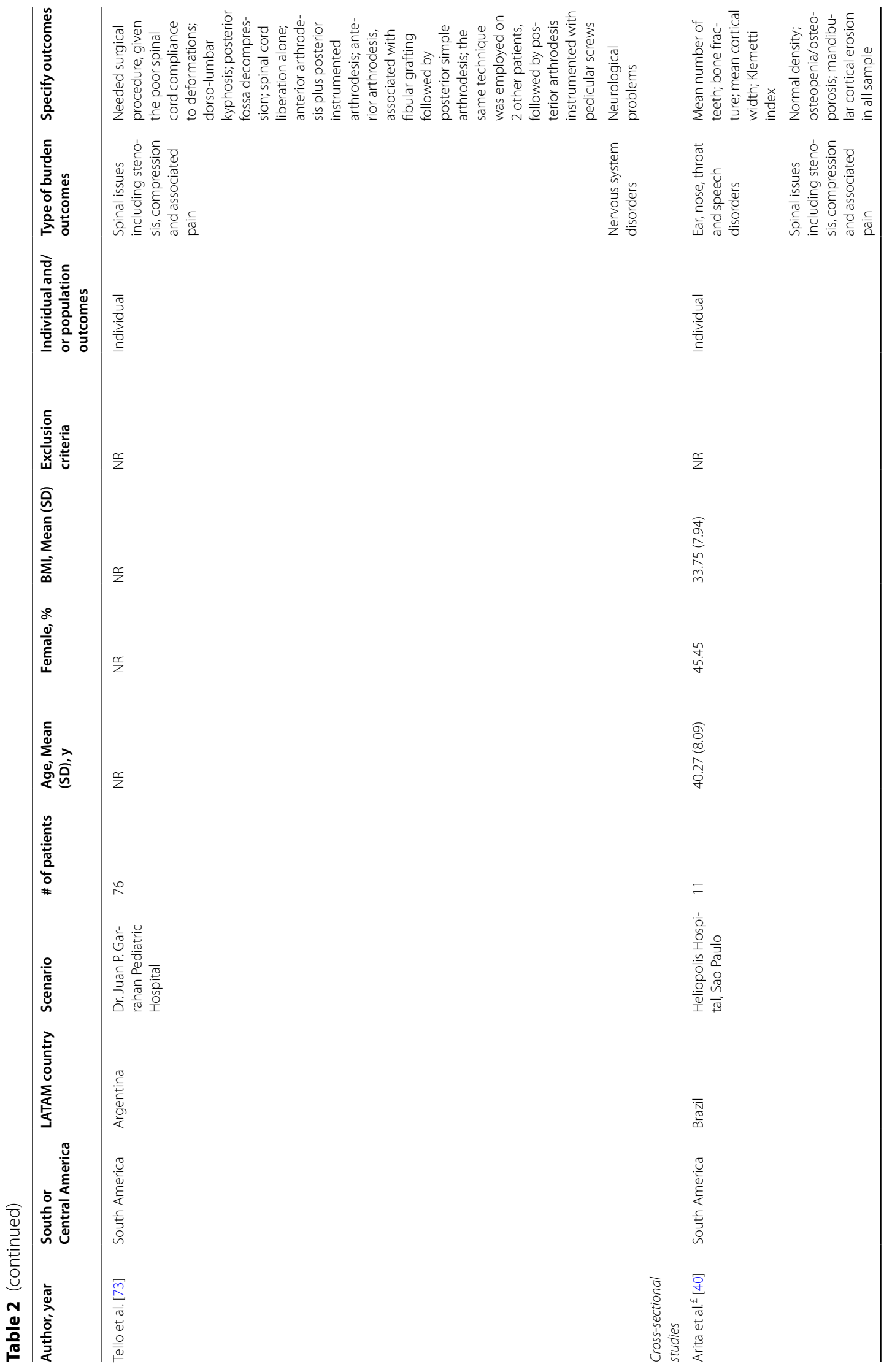




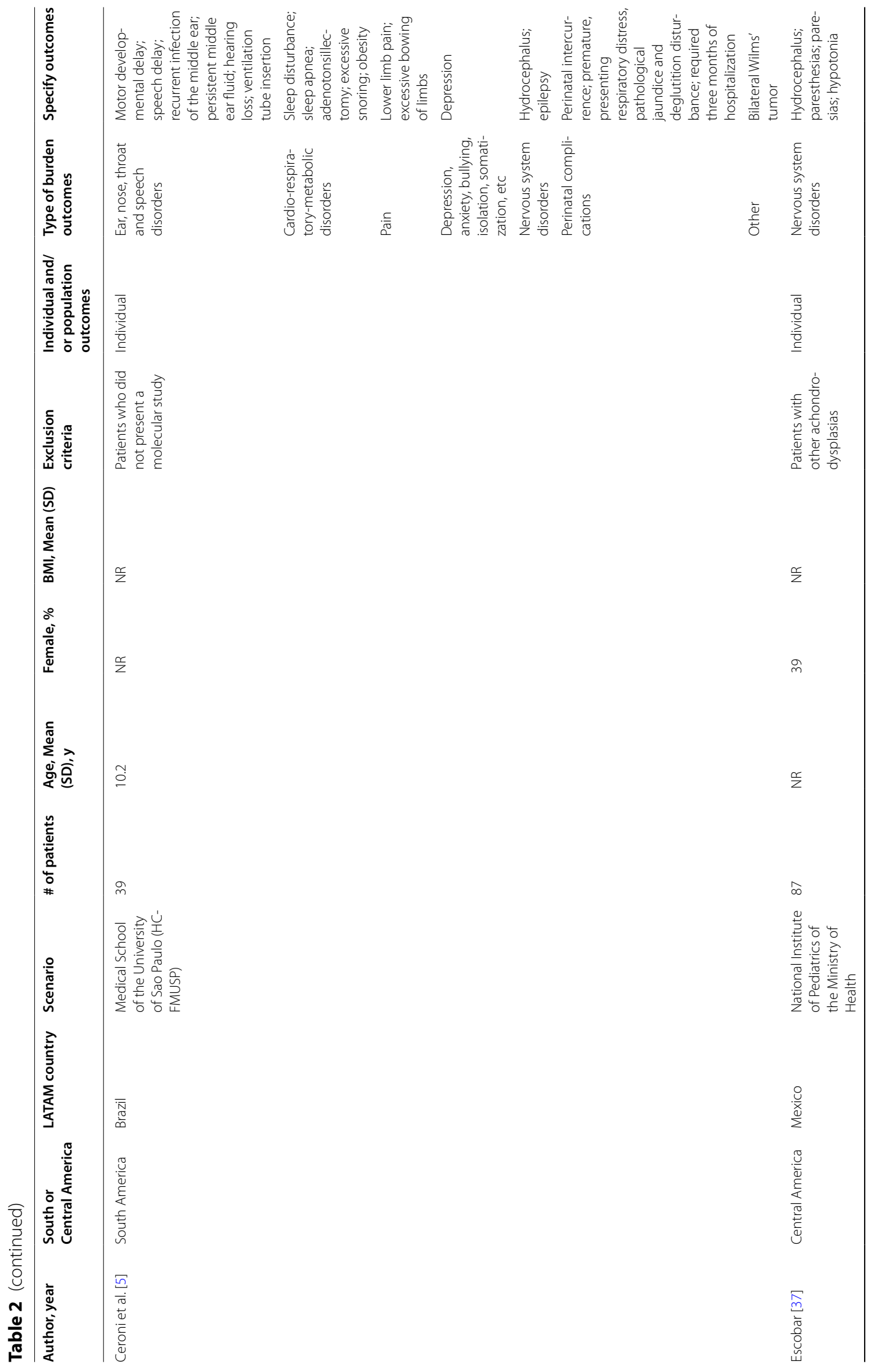




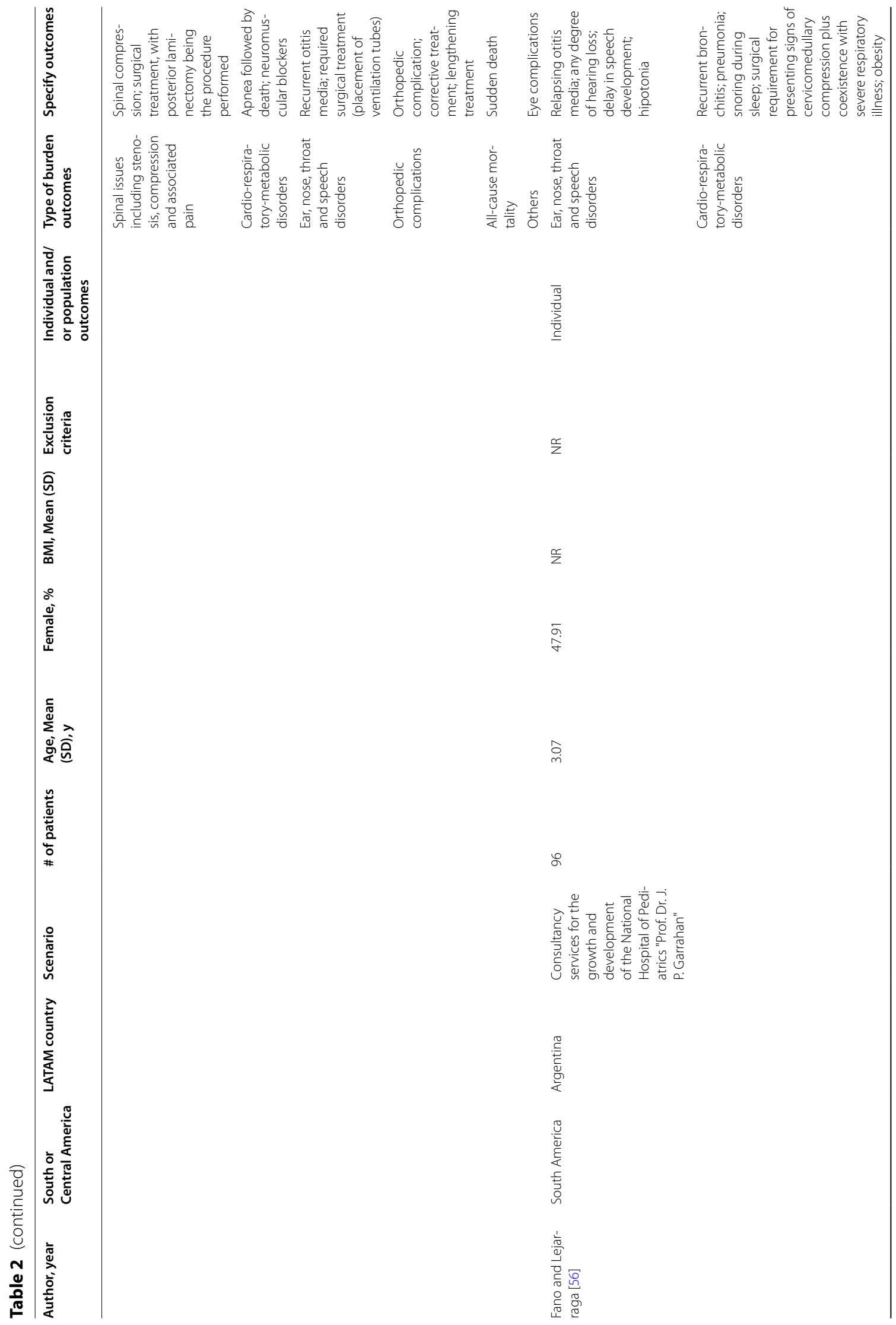




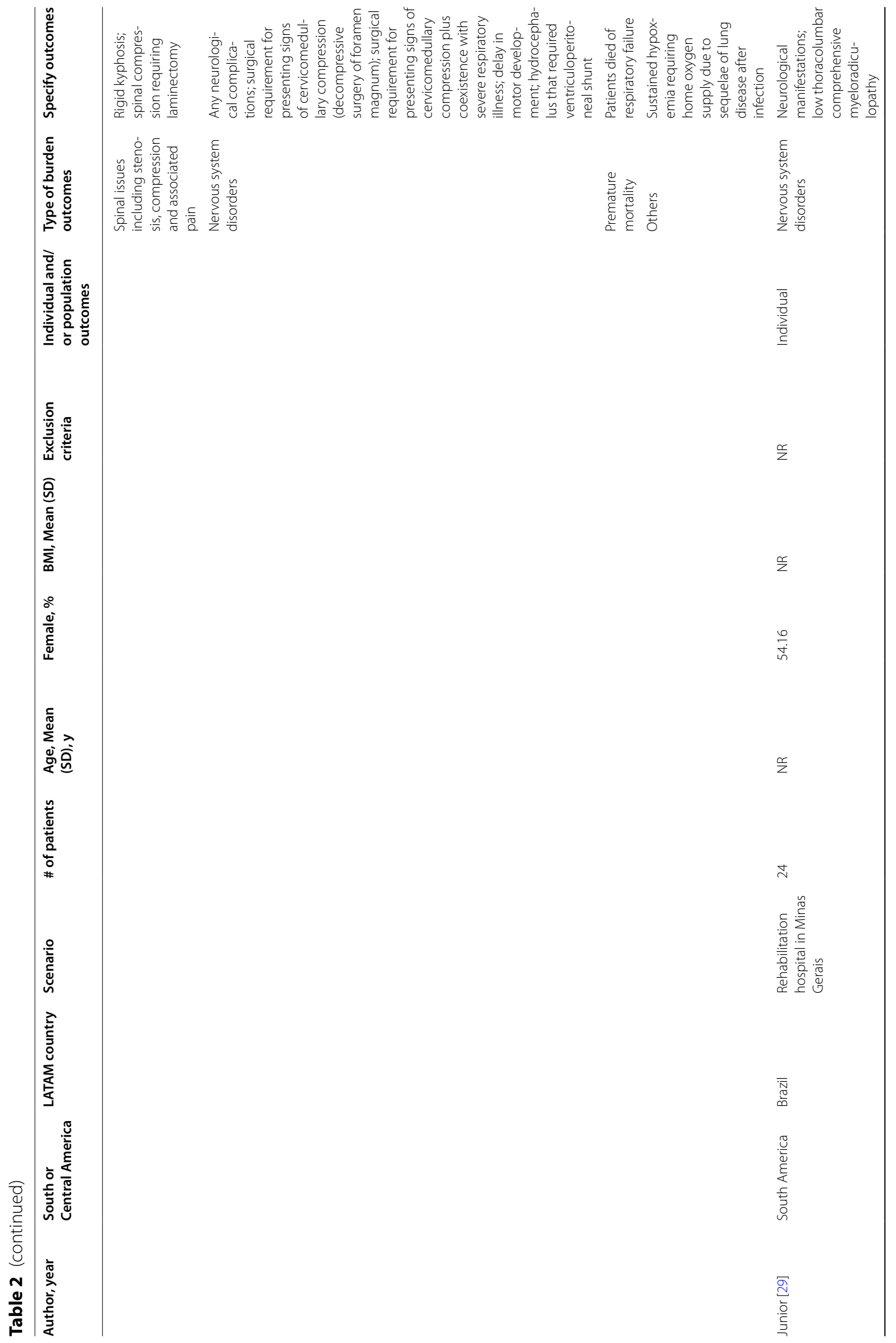




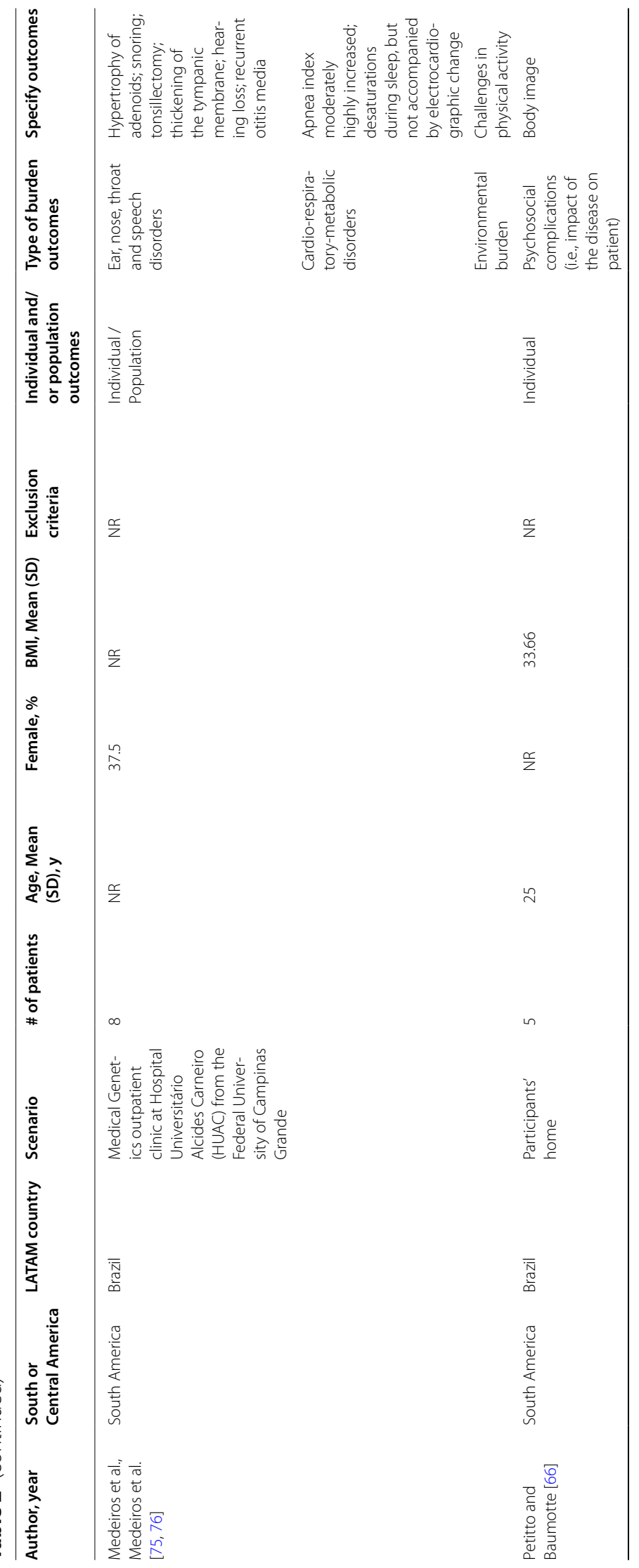




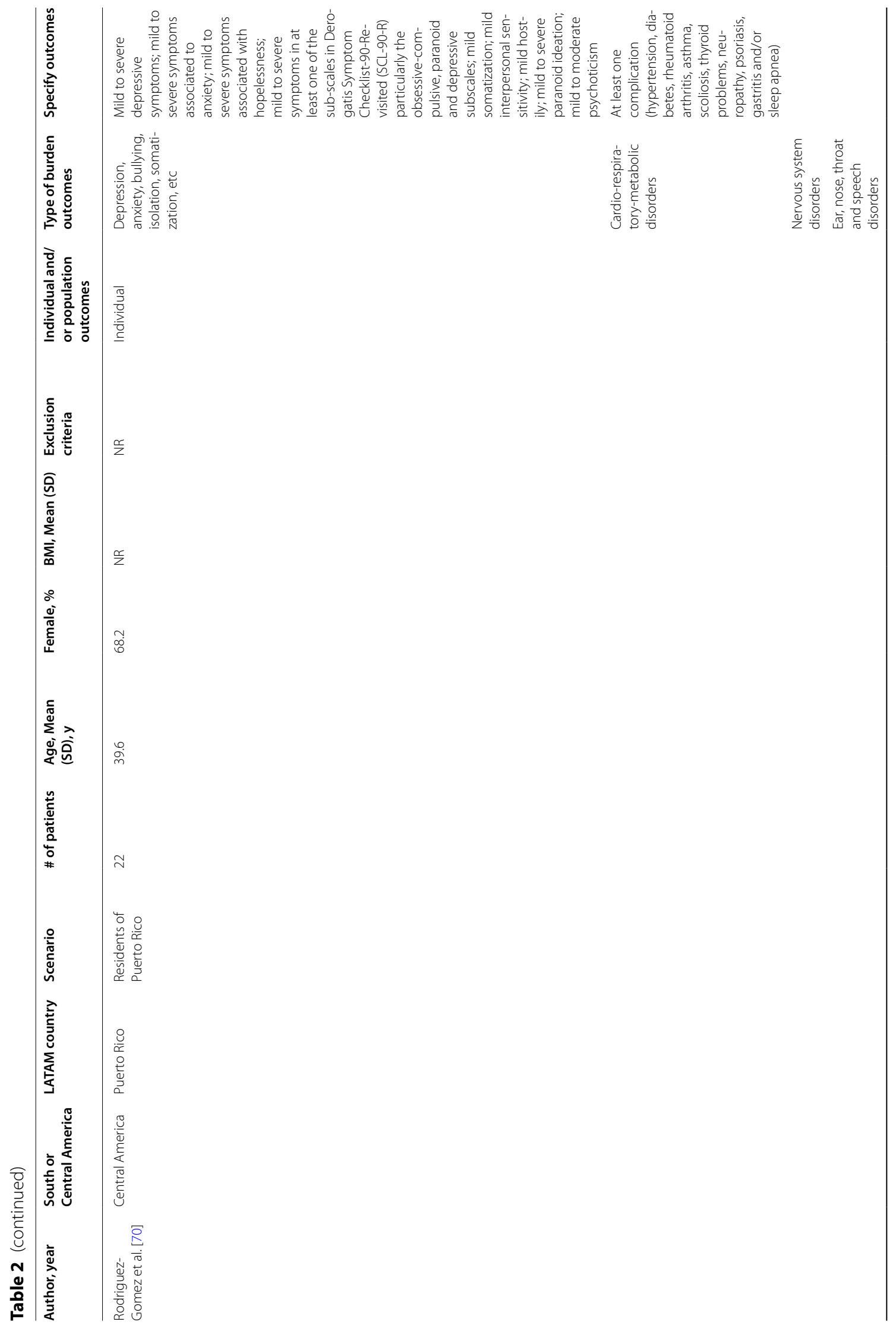




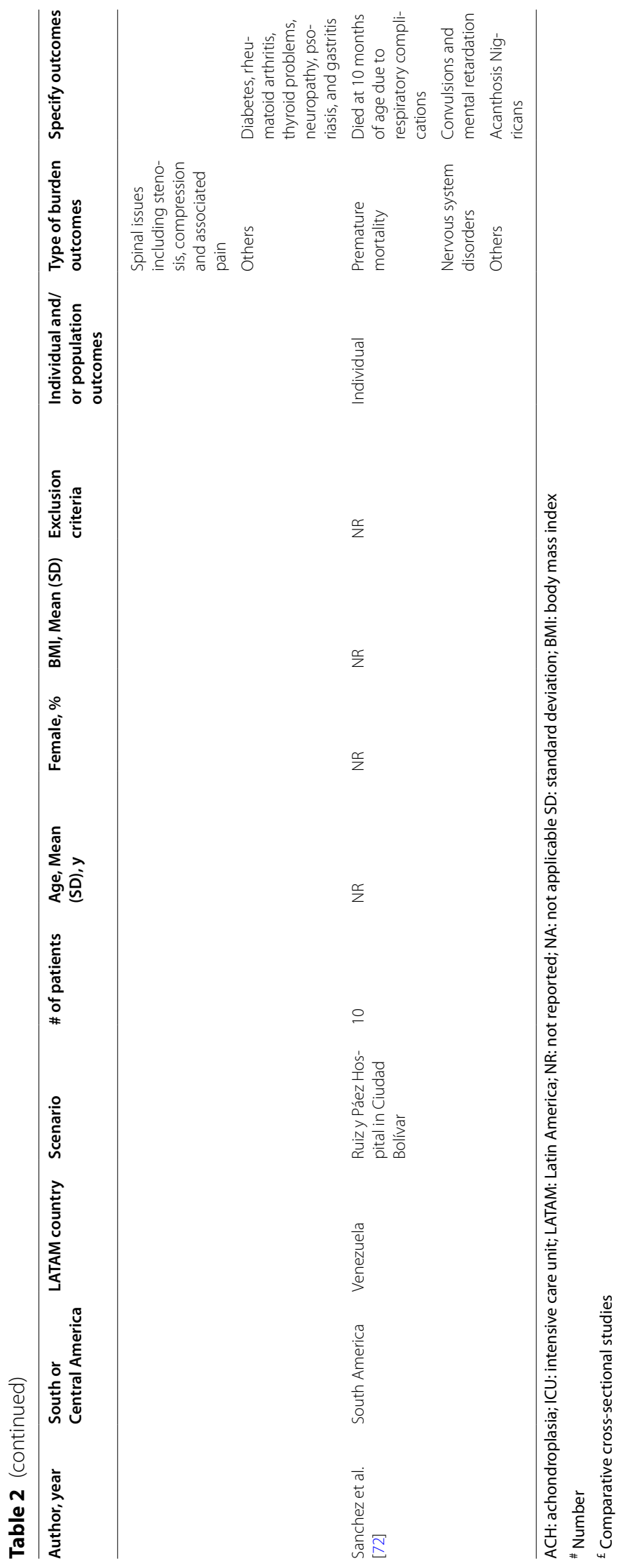




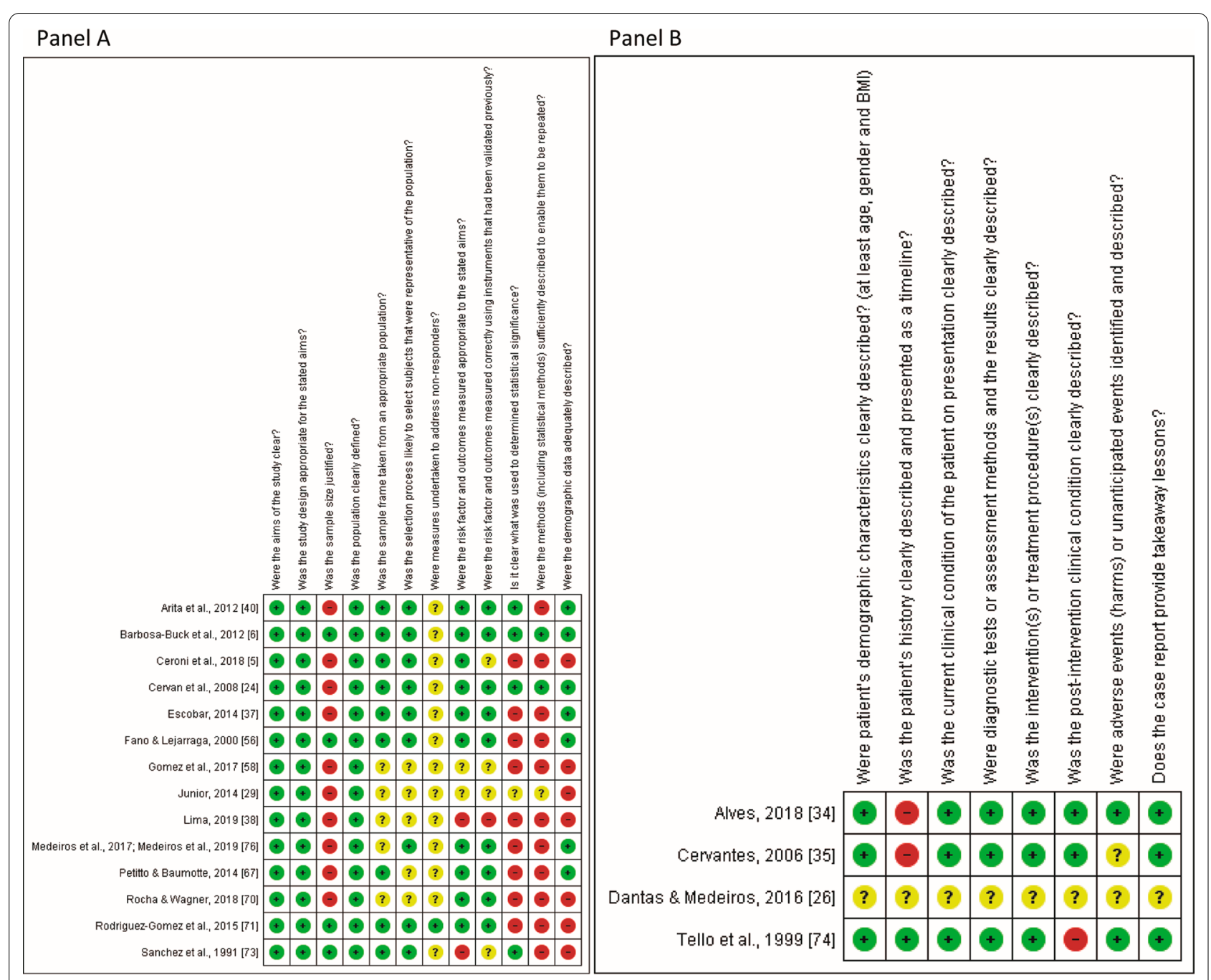

Fig. 2 Risk of bias assessment of the included studies. a Cross-sectional studies. b Case series studies

found evidence of the impact of $\mathrm{ACH}$ on affected individuals in LATAM. Case-series and cross-sectional studies provide pooled proportions of burden ranging from $15 \%$ (mortality) to $32 \%$ (for ear, nose, throat and speech disorders outcomes).

We have now applied a methodology [21, 22] to evaluate the proportions of clinical burden outcomes in the LATAM ACH population. The proportions of pooled case series and cross-sectional studies were consistent with results from only pooled cross-sectional studies in the outcomes of nervous system disorders and spinal issues including stenosis, compression and associated pain, meaning that the assumed proportions lie in a high probability of a true value. To the best of our knowledge, this is the first study to clearly demonstrate the burden of LATAM ACH patients, an observation that should be taken into account in regional health policy debates regarding management of $\mathrm{ACH}$ disease. Of note, while limb lengthening procedures are frequently performed on ACH patients in LATAM, we were not able to find any data on these procedures in the included studies.

\section{Strengths and limitations}

Strengths of our review include a comprehensive search; assessment of eligibility, risk of bias and data abstraction independently and in duplicate; and an assessment of risk of bias that included a sensitivity analysis addressing homogeneity of study designs.

The primary limitation of our study is related to the rare disease nature of $\mathrm{ACH}$. The population available to study was limited and the study designs presented some flaws. 


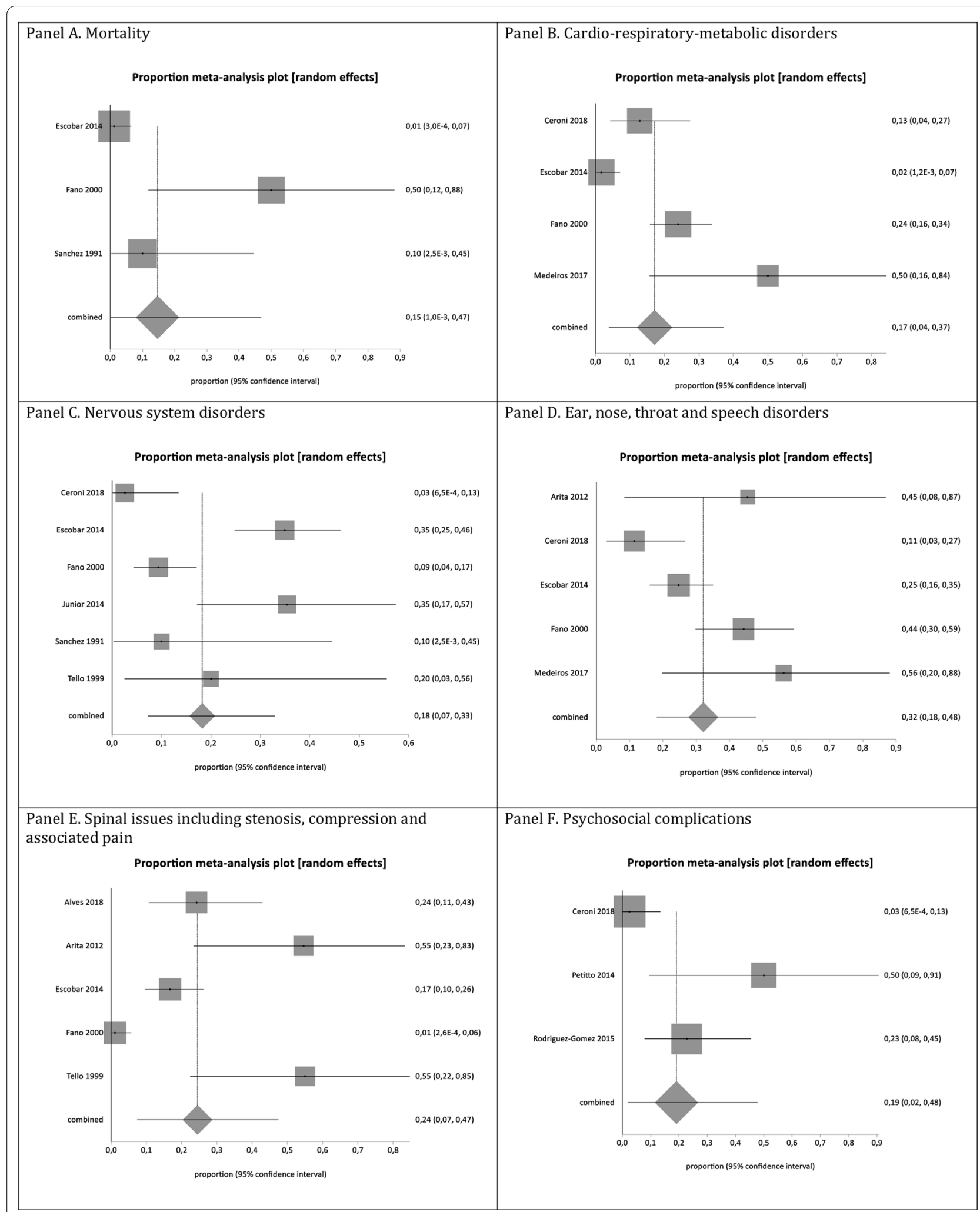

Fig. 3 Pooled analysis of proportions for burden outcomes in LATAM ACH patients. a Mortality. b Cardio-respiratory-metabolic disorders. c Nervous system disorders. $\mathbf{d}$ Ear, nose, throat and speech disorders. e Spinal issues including stenosis, compression and associated pain. $\mathbf{f}$ Psychosocial complications. $\mathbf{g}$ Others 
Panel A. Sensitivity analysis of nervous system disorders.

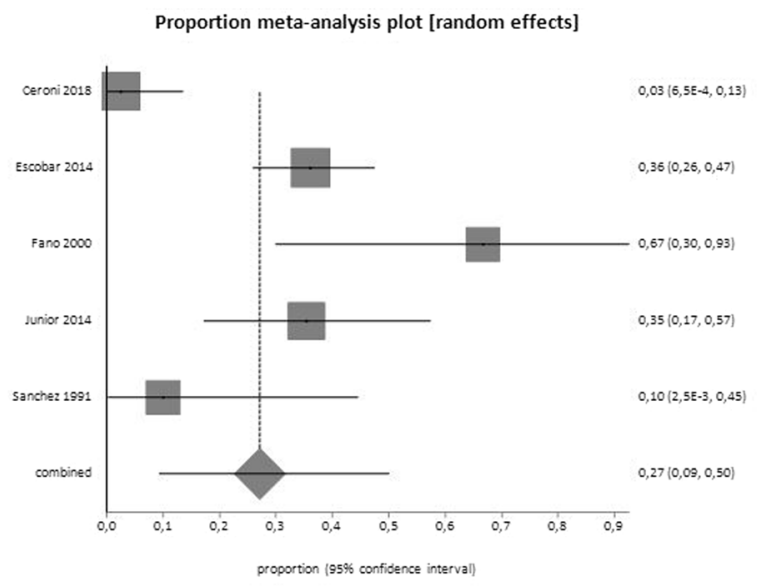

Panel B. Sensitivity analysis of spinal issues including stenosis, compression and associated pain

Proportion meta-analysis plot [random effects]

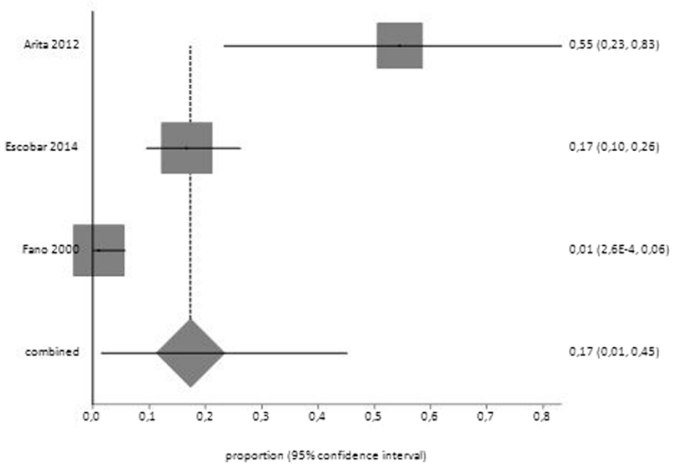

Fig. 4 Sensitivity analysis excluding case series studies from the cross-sectional studies for burden outcomes in LATAM ACH patients. Panel A: Nervous system disorders. Panel B: Spinal issues including stenosis, compression and associated pain.

Another limitation is that our analysis demonstrates a significant heterogeneity $\left(\mathrm{I}^{2}\right)$ in all studied clinical burden outcomes. Explanations for this heterogeneity could be both clinical and methodological diversities. The studies differed considerably in their mean age of patient selection, study designs (i.e., case series, cross-sectional, and case reports), and type of burden outcomes (e.g., nervous system disorders, one study could report hydrocephalus, while another reports epilepsy).

Furthermore, out of the 53 clinical studies we were only able to include data in the meta-analysis from 11 of them (20.4\%). The majority of the studies were difficult to decipher, and they did not provide all burden pre-defined outcomes.

A further limitation was the insufficient number of studies, which prevented completing statistical analyses that had initially been planned. We were unable to assess publication bias because there were less than 10 eligible studies addressing the same outcome in a meta-analysis. Subgroup analyses on LATAM countries (e.g., Brazil versus Argentina), and adults versus children were not possible since minimal criteria were not met (i.e., at least four studies available, with at least two in each sub-group).

A sensitivity analysis pooling all included studies (i.e., case series and cross-sectional studies) compared with pooling only the cross-sectional studies was only possible for nervous system disorders and spinal issues outcomes. No difference was found in the proportion of overlap CIs between both analyses.

\section{Relation to prior research}

Unfortunately, there is a dearth of information on LATAM patients in both non-English and Englishlanguage medical literature on $\mathrm{ACH}$. While we found a $15 \%$ mortality rate in our review, with a wide-ranging prevalence from 0.1 to $47 \%$, a multicenter study of mortality in $\mathrm{ACH}$ [77] that studied 855 USA patients presented an overall mortality rate of $99 \%$ per 1,000 person years, with an absolute number of deaths of 12 patients $(\mathrm{n}=5$, toddlers; $\mathrm{n}=2$, young children; and $\mathrm{n}=5$, young adulthood). The authors of the clinical study also found that the infant mortality rate was $3.2 / 1,000$ person years. Although only three studies $[37,56,72]$ contributed to our data on mortality, only one of them [56] reported the mean age of the population as 3.07 years old. Therefore, in our systematic review, $33.33 \%$ of the mortality data is contributed from predominantly children with a mean age of three years. Another two studies have estimated the maximal risk of deaths in the first year of life as $7.5 \%[2,9]$; this high percentage may also be explained due to the absence of special care and surgical intervention.

Furthermore, an additional two studies [78, 79] identified in the literature corroborate with our findings showing that motor delays are common in the $\mathrm{ACH}$ population. In our review, we found a prevalence of nervous system disorders, which encompassed motor delay, of $26 \%$ with a reasonable CI ranging from 12 to $44 \%$. 
A high prevalence of ear, nose, and throat disorders $(32 \%)$ and spinal issues $(26 \%)$ were found in our review which is consistent with other studies indicating that middle ear dysfunction [80] and spinal stenosis [81] are highly common in both children and adults with $\mathrm{ACH}$.

\section{Conclusions}

LATAM ACH patients presented a high prevalence of clinical complications, although the possibility of residual confounding due to lack of adequate reports in this population and high heterogeneity in the analysis cannot be ruled out. This study also highlights the need to address well-conducted clinical studies on $\mathrm{ACH}$, and to alert the public health authorities. Future observational studies should have standardized outcomes measures such as mortality, physical comorbidities, humanistic outcomes, and socioeconomic and environmental burden outcomes.

\begin{abstract}
Abbreviations
ACH: Achondroplasia; LATAM: Latin American; ECLAMC: Latin American Collaborative Study of Congenital Malformations; PRISMA: Preferred Reporting Items for Systematic Review and Meta-Analysis; MOOSE: Meta-analysis of Observational Studies in Epidemiology; PROSPERO: International Prospective Register of Systematic Reviews; BPI-SF: Brief Pain Inventory-Short Form; QoLiSSY: Questionnaire, the Quality of Life Short Stature Youth; PedsQL: Questionnaire, and the Pediatric Quality of Life Inventory; WPAI-SHP: Work and Productivity and Activity Impairment; MeSH: Medical Subject Headings; MEDLINE: Medical Literature Analysis and Retrieval System Online; EMBASE: Excerpta Medica Database; CENTRAL: Cochrane Central Register of Controlled Trials; LILACS: Latin American and Caribbean Health Sciences Literature; SciELO: Scientific Electronic Library Online; IBECS: Spanish Bibliographic Index of the Health Sciences; BINACIS: National Bibliography in Health Sciences Argentina; MedCarib: Caribbean Health Sciences Literature; CUMED: National Medical Sciences Information Center of Cuba; BBO: Brazilian Bibliography of Dentistry; ANVISA: National Health Surveillance Agency; BDTD: Brazilian Digital Library of Theses and Dissertations; BMI: Body mass index; JBI: Joanna Briggs Institute; QoL: Quality of life; Cl: Confidence Interval.
\end{abstract}

\section{Supplementary Information}

The online version contains supplementary material available at https://doi. org/10.1186/s13023-021-02142-3.

\section{Additional file 1. Search strategy.}

Additional file 2. Ten LATAM ACH included studies evaluating other than patient-important or economic burden outcomes.

Additional file 3. Reported burden outcomes on 25 LATAM ACH case reports studies.

Additional file 4. Risk of bias for cross-sectional studies.

Additional file $\mathbf{5}$. Risk of bias for case series studies.

\section{Acknowledgements}

This manuscript was prepared according to the International Society for Medical Publication Professionals-Good Publication Practice for Communicating Company-Sponsored Medical Research: the GPP3 Guidelines.

\section{Authors' contributions}

All authors contributed to study design, interpretation, and analysis. CAK, PR, RED, RS, TM, DM and JLJ were responsible for data identification, extraction, and synthesis. VF was responsible for creating the first draft. All authors read and approved the final manuscript.

\section{Funding}

Funding to support this study and the preparation of this manuscript was provided by Biomarin Farmaceutica LTDA.

\section{Availability of data and materials}

All data generated or analysed during this study are included in this published article and its supplementary information files.

\section{Declarations}

Ethics approval and consent to participate

Not applicable.

\section{Consent for publication}

Not applicable.

\section{Competing interests}

RED has received a consulting fee from Biomarin Farmaceutica LTDA. The other authors have declared no conflict of interests.

\section{Author details}

${ }^{1}$ Hospital de Pediatría "Prof. Dr. Juan P. Garrahan", Buenos Aires, Argentina. ${ }^{2}$ Instituto da Criança HC - FMUSP, São Paulo, SP, Brazil. ${ }^{3}$ Fundacion Cardioinfantil-Instituto de Cardiologia, Bogotá, Colombia. ${ }^{4}$ UNESP - Univ Estadual Paulista, Department of Biosciences and Oral Diagnosis, Institute of Science and Technology, São José Dos Campos, SP, Brazil. ${ }^{5}$ BioMarin Pharmaceutical Inc, Novato, CA, USA. ${ }^{6}$ Medical Affairs Latin America, BioMarin Farmaceutica LTDA, São Paulo, SP, Brazil. ${ }^{7}$ Instituto Nacional Fernandes Figueira (IFF), Fundação Osvaldo Cruz, Av. Rui Barbosa 716, Rio de Janeiro, RJ 22250 020, Brazil.

Received: 31 May 2021 Accepted: 28 November 2021

Published online: 04 January 2022

\section{References}

1. Shirley ED, Ain MC. Achondroplasia: manifestations and treatment. J Am Acad Orthop Surg. 2009;17:231-41.

2. Wynn J, King TM, Gambello MJ, Waller DK, Hecht JT. Mortality in achondroplasia study: a 42-year follow-up. Am J Med Genet A. 2007:143A:2502-11

3. Gorlin RJ, Cohen MM, Levin LS. Syndromes of the head and neck. New York: Oxford University Press; 1990. p. 171-4.

4. Foreman PK, van Kessel F, van Hoorn R, van den Bosch J, Shediac R, Landis S. Birth prevalence of achondroplasia: a systematic literature review and meta-analysis. Am J Med Genet A. 2020;182(10):2297-316. https://doi. org/10.1002/ajmg.a.61787.

5. Ceroni JRM, Soares DCQ, Testai LC, et al. Natural history of 39 patients with Achondroplasia. Clinics. 2018;73:e324. https://doi.org/10.6061/clini cs/2018/e324.

6. Barbosa-Buck CO, Orioli IM, da Graça DM, Lopez-Camelo J, Castilla EE, Cavalcanti DP. Clinical epidemiology of skeletal dysplasias in South America. Am J Med Genet A. 2012;158A(5):1038-45. https://doi.org/10. 1002/ajmg.a.35246.

7. Duarte SP, Rocha ME, Bidondo MP, Liascovich R, Barbero P, Groisman B. Bone dysplasias in 1.6 million births in Argentina. Eur J Med Genet. 2019;62(12):103603. https://doi.org/10.1016/j.ejmg.2018.12.008.

8. ECLAMC. Estudio Colaborativo Latinoamericano de Malformaciones Congenitas. http://www.eclamc.org. Cited 15 Dec 2020.

9. Hecht JT, Francomano CA, Horton WA, Annegers JF. Mortalityinachondroplasia. Am Hum Genet. 1987:41:454-64.

10. Hoover-Fong J, Cheung MS, Fano V, Hagenas L, Hecht JT, Ireland P, Irving M, Mohnike K, Offiah AC, Okenfuss E, Ozono K, Raggio C, Tofts L, Kelly D, Shediac R, Pan W, Savarirayan R. Lifetime impact of achondroplasia: current evidence and perspectives on the natural history. Bone. 2021;2:115872. https://doi.org/10.1016/j.bone.2021.115872. 
11. Gollust SE, Thompson RE, Gooding HC, Biesecker BB. Living with achondroplasia in an average-sized world: an assessment of quality of life. Am J Med Genet A. 2003;120A(4):447-58. https://doi.org/10.1002/ajmg.a. 20127.

12. Clopper RR, MacGillivray MH, Mazur T, Voorhess ML, Mills BJ. Posttreatment follow-up of growth hormone deficient patients: Psychosocial status. In: Stabler B, Underwood LE, editors. Slow grows the child: Psychosocial aspects of growth delay. Hillsdale: Lawrence Erlbaum Associates; 1986. p. 83-96.

13. Dean HJ, McTaggert TL, Fish DG, Friesen HG. Long-term social followup of growth hormone deficient adults treated with growth hormone during childhood. In: Stabler B, Underwood LE, editors. Slow grows the child: psychosocial aspects of growth delay. Hillsdale: Lawrence Erlbaum Associates; 1986. p. 73-82

14. Mitchell CM, Johanson AJ, Joyce S, Libber S, Plotnick L, Migeon CJ, Blizzard RM. Psychosocial impact of long-term growth hormone therapy. In: Stabler B, Underwood LE, editors. Slow grows the child: psychosocial aspects of growth delay. Hillsdale: Lawrence Erlbaum Associates; 1986. p. 97-110.

15. Richman RA, Gordon M, Tegtmeyer P, Crouthamel C, Post EM. Academic and emotional difficulties associated with constitutional short stature. In: Stabler B, Underwood LE, editors. Slow grows the child: psychosocial aspects of growth delay. Hillsdale: Lawrence Erlbaum Associates; 1986. p. 13-26.

16. Moher D, Liberati A, Tetzlaff J, et al. Preferred reporting items for systematic reviews and meta-analyses: the PRISMA statement. BMJ. 2009:339:b2535.

17. Stroup DF, Berlin JA, Morton SC, Olkin I, Williamson GD, Rennie D, et al. Meta-analysis of observational studies in epidemiology: a proposal for reporting. Meta-analysis Of Observational Studies in Epidemiology (MOOSE) group. JAMA. 2000;283:2008-12.

18. Guyatt GH, Busse JW. Modification of Ottawa-Newcastle to assess risk of bias in nonrandomized trials. http://distillercer.com/resources/.

19. Downes MJ, Brennan ML, Williams HC, et al. Development of a critical appraisal tool to assess the quality of cross-sectional studies (AXIS). BMJ Open. 2016;6:e011458. https://doi.org/10.1136/bmjop en-2016-011458.

20. Gagnier JJ, Kienle G, Altman DG, Moher D, Sox H, Riley D, et al. The CARE guidelines: consensus-based clinical case report guideline development. J Clin Epidemiol. 2014;67(1):46-51.

21. El Dib R, Touma NJ, Kapoor A. Cryoablation versus Radiofrequency Ablation for the Treatment of Renal Cell Carcinoma: a meta-analysis of case series studies. BJU Int. 2012;110:510-6.

22. El Dib R, Nascimento P Jr, Kapoor A. An alternative approach to deal with the absence of clinical trials: a proportional meta-analysis of case series studies. Acta Cir Bras. 2013;28:870-6.

23. DerSimonian R, Laird N. Meta-analysis in clinical trials. Control Clin Trials. 1986;7:177-88.

24. Cervan MP, PiresdaSilva MC, Lima RLO, FernandesdaCosta R. Comparative study of quality of life level between achondroplasics and nonachondroplasics subjects. J Bras Psiquiatr. 2008;57(2):105-11.

25. Higgins JP, Thompson SG, Deeks JJ, Altman DG. Measuring inconsistency in meta-analyses. BMJ. 2003;327:557-60.

26. Dantas CMF, de Medeiros PFV. Perfil clínico e epidemiológico de pacientes com acondroplasia Campina Grande - Paraíba. XIII Congresso de iniciação científica da Universidade Federal de Campina Grande. 2016

27. Galego CNF, da Silva SA, Mendes SQ, Braga FSS, Brandão MJN. Anestesia geral em paciente acondroplásica. Sao Paulo Med. J. 2018;136(Suppl).

28. Jesus LG, Gil JA, Lopes ACA, Ozomo FH. Raquianestesia para gestante acondroplasia. $64^{\circ}$ Congresso Brasileiro de Anestesiologia. 2017. TLP725. S64.

29. Junior ALC. Alterações do esqueleto axial e complicações neurológicas na acondroplasia [tese]. Universidade Federal de Minas Gerais. 2014

30. Nascimento DB, Carolino WM, Dias CAD, Gonçalo MG, Bersot CDA. Anestesia para gastroplastia videolaparoscópica em portadora de acondroplasia: relato de caso. AESP016. p. 35. 2015.

31. Oliveira GJR, Foresti C, Telles FF, Lima WLF. Anestesia peridural para cesariana em paciente acondroplásica pós cirurgia bariátrica. AOBS012. p. 35. 2015
32. Tosato LG, Alves AK. Relato de caso: Anestesia em cesárea de paciente portadora de nanismo acondroplásico. TLO944. S65. 2017.

33. Werb J, Gomes KEC, Condeixa GD, Braga ELC, Cabral DIS, et al. Anestesia em paciente acondroplásica com vasculopatia periférica. S121. 2016.

34. Alves FA. Acondroplasia e suas implicações neurocirúrgicas em uma série de casos pediátricos [tese]. Fundação Oswaldo Cruz Instituto Nacional de Saúde da Mulher, da Criança e do Adolescente Fernandes Figueira. Rio de Janeiro, p. 103. 2018.

35. Cervantes CC. Eficacia de los ejercicios de flexion de columna y la electroterapia combinados en la correccion de la hiperlordosis lumbar em niños com acondroplasia [tesis]. Trabajo de tesis, Facultad de medicina Division de estúdios de posgrado e investigacion secretaria de salud instituto nacional de pediatria. México, p. 34. 2006.

36. Costa JLM. Antropometria, dermatoglifia e qualidades físicas básicas de atletas de futebol, portadores de acondroplasia da cidade de Belém-PA. [Tese]. Universidade Castelo Branco. Rio de Janeiro, p. 170. 2010.

37. Escobar IG. Acondroplasia: revision de 30 años en el Instituto Nacional de Pediatria [tesis]. Facultad de medicina división de estudios de posgrado e investigación secretaría de salud Instituto Nacional de Pediatría. México, p. 20. 2004.

38. Lima, MP. Compreensão psicossocial da vida de trabalho para pessoas com nanismo: entre a estigmatização e o reconhecimento [tese]. Universidade Federal de Minas Gerais. São Paulo, p. 166. 2019

39. Abrão MA, da Silveira VG, de Almeida Barcellos CF, Cosenza RC, Carneiro $J R$. Anesthesia for bariatric surgery in an achondroplastic dwarf with morbid obesity. Rev Bras Anestesiol. 2009;59(1):79-86. https://doi.org/10. 1590/s0034-70942009000100011.

40. Arita ES, Pippa MG, Marcucci M, et al. Assessment of osteoporotic alterations in achondroplastic patients: a case series. Clin Rheumatol. 2012;32(3):399-402. https://doi.org/10.1007/s10067-012-2126-x.

41. Arlet CT, Leslie RRD, Erika KV, Erika ED, Jennifer AS, et al. Ortopedia en acondroplasia primera fase: Reporte de un caso. Rev Tamé. 2016:4(12):433-5.

42. Benavides L, Heredia RD, Sauza N, Meléndez-Flórez HJ. Spinal anesthesia for cesarean section in a patient with achondroplasia: case report. Colomb J Anesthesiol. 2018:46(4):331-5.

43. Calderón MY, González RMR, Occeguera MAC, Salvat RMG. Acondroplasia. Reporte de um caso. RevCOG. 2010;15(1):30-2.

44. Carbia SG, Malah V, Wappner D, Carbia C, Glorio R, et al. Metástasis cutánea sobre cicatriz por carcinoma de esófago en acondroplásica Comunicación de un caso diagnosticado por punción aspiración con aguja fina. Arch Argent Dermatol. 2003:53:119-22.

45. Cardoso R, Ajzen S, Andriolo AR, Xavier de Oliveira J, Andriolo A. Analysis of the cephalometric pattern of Brazilian achondroplastic adult subjects. Dental Press J Orthod. 2012;17(6):118-29.

46. Carmen CAN, Roberto HCJ, Paulina GV, Nayghit CCY, Pablo LBL, et al. Achondroplasia, risk factor in pregnancy. Revista Universitaria con proyección cientifica, académica y social. 2019;3(1):8-12. https://doi.org/10. 31243/mdc.uta.v3i1.164.2019.

47. Carolina DS, Violeta HJ, Verónica MV. Estenosis acueductal en acondroplasia: A propósito de un caso. Rehabil Integral. 2010;5(2):95-8.

48. Castro A, Gutiérrez A, Rodríguez LF, Pineda T, Velasco H, et al. Análisis mutacional de la acondroplasia em 20 pacientes colombianos. Rev Fac Med. 2010;58(3):185-90.

49. Castro EM, Vendramini JB, da Silva BD, de Oliveira GC, Righetti RG. Análise comparativa da pisada durante a marcha de um indivíduo portador de acondroplasia e um não acondroplásico do sexo feminino. 2012. $10^{\circ}$ Simpósio de ensino de graduação (UNIMEP).

50. Del Pino M, Fano V, Lejarraga $H$. Growth references for height, weight, and head circumference for Argentine children with achondroplasia. Eur J Pediatr. 2010;170(4):453-9. https://doi.org/10.1007/s00431-010-1302-8.

51. Del Pino M, Fano V. Referencias de indice de masa corporal para niños com acondroplasia. Med Infant. 2013;XX:80-4.

52. Del Pino M, Fano V , Adamo P. Growth velocity and biological variables during puberty in achondroplasia. J Pediatr Endocrinol Metab. 2018:31(4):421-8. https://doi.org/10.1515/jpem-2017-0471.

53. Del Pino M, Mejía RR, Fano V. Leg length, sitting height, and body proportions references for achondroplasia: new tools for monitoring growth. Am J Med Genet A. 2018;176(4):896-906. https://doi.org/10.1002/ajmg.a. 38633. 
54. Del Pino M, Fano V, Adamo P. Height growth velocity during infancy and childhood in achondroplasia. Am J Med Genet A. 2019;179(6):1001-9. https://doi.org/10.1002/ajmg.a.61120.

55. Eusebio MP, Elisabeth VM. Alargamento femoral bilateral em ele nanismo primer caso em republica dominicana. Acta Médica Dominicana. 1991;13(5):173-6.

56. Fano $\mathrm{V}$, Lejarraga $\mathrm{H}$. Hallazgos frecuentes en la antención clínica de 96 niños con acondroplasia. Arch Argent Pediatr. 2000;98(6):368-75.

57. Frade LYT, Oliveira J, Lacerda de Jesus JA. Acondroplasia: diagnóstico clínico precoce. Brasília Med. 2012;49(4):302-5.

58. Gomez ELL, Ruiz MMA, Valderrama MS, Velásquez RSM, Calderón LFA, et al. Application of design thinking methodology in footwear design for persons with achondroplasia in Colombia. Congreso Internacional de Innovacion y Tendencias en Ingenieria (CONIITI). 2017:1-6. doi: https:// doi.org/10.1109/CONIITI.2017.8273361.

59. Hernández-Motiño LC, Brizuela YS, Vizcarra V, Revilla RC, Balderas LJ, et al. Achondroplasia — spinal canal stenosis-a neurological complication. Bol Med Hosp Infant Mex. 2012;69(1):46-9.

60. Lotti FA, Muñiz IC, Oteiza MEF, Ortiz JR, González PC, et al. Caracterización patogénica de los recién nacidos con malformaciones múltiples. Rev Cubana Pediatr. 1998;70(2):73-8.

61. Mancilla EE, Poggi H, Repetto G, Garcia C, Foradori A, et al. Mutaciones del gen del receptor 3 del Factor de Crecimiento de Fibroblasto (FGFR3) em pacientes chilenos con talla baja idiopática, hipocondroplasia y acondroplasia. Rev Med Chile. 2003;131:1405-10.

62. Medina J, Espínola CM, González G, Sostoa G. Achondroplasia (AC) and its Neurological Complications: a Case Report. Pediatr (Asunción). 2008;35(1):24-8.

63. Morais BS, Cruvinel MGC, Silva YP, Diniz DA, Viana de Castro CH. Bilateral Blockade of the Pudend Nerve to Hemorrhoidectomy in Achondroplasic Patient. Case Report. Rev. Bras. de Anestesiol. 2006;56(2):168-173.

64. Muratore A, Viollaz GM. Elongación humeral en la acondroplasia: Presentación de un caso. Rev Asoc Argent Ortop Tramatol. 2010;76:161-4.

65. Palmira LEL, Rabasa SIL, León AF, Rodríguez GSG, Rodrígues JHD. A difficult airway in na obstetrics patient presenting with achondroplasia. Revista Cubana de Anestesiología y Reanimación. 2012;11(2):130-8.

66. Petitto $M$, Baumotte FA. Métodos de avaliação nutricional em indivíduos acondroplásicos. Centro Universitário de Brasília - UniCEUB, Faculdade de Ciências da Educação e Saúde. Brasília, p. 19. 2014.

67. Pimentel RFW, Figueiredo PCM. Parenteral nutrition therapy for an acondroplásico: Relato de caso. Int J Nutrol. 2019;12:61-5. https://doi.org/10. 1055/s-0039-3402023.

68. Posada RID, Álvarez KP, Montoya JFA, Arévalo DPO. Monitorización com potenciales evocados somatosensoriales durante la descompresión occipitocervical en um lactante com acondroplasia: reporte de um caso. latreia. 2005;18(2):177-84.

69. Rocha L, Wagner D. Pessoas com nanismo acondroplasia: um estudo acerca dos aspectos psicossociais e as contribuições da atividade física na sua inclusão social. Ciência em Movimento / Educação e Direitos Humanos. 2018;20(40):17-29.

70. Rodriguez-Gomez J, Aldarondo A, Vidot F, Quiñones A, Rivera M, Cintrón E, et al. Acondroplasia: Un Estudio Pionero Sobre Las Características Psicosociales Y Médicas De Una Muestra En Puerto Rico. PRMA Boletim. 2015;107(3):58.

71. Rudas WO, García NIS, Upegui A, Medina AR, Moran A, et al. Anestesia para cesárea en paciente con acondroplasia. Rev Colomb Anestesiol. 2012;40(4):309-12. https://doi.org/10.1016/j.rca.2012.07.002.

72. Sanchez O, Brito-Arreaza, Avarez-Arratia MC, Ramírez N. Prevalencia de Displasias Esqueléticas en Recién Nacidos en el Hospital Ruíz y Páez de Ciudad Bolívar. Venezuela. Período 1978-1990. Invest. Clin. 1991;32(2):67-76.

73. Tello C, Bersusky E, Wilson AF, Noel M, Klappenbach H. El raquis en la acondroplasia. Rev Asoc Arg Ortop y Traumatol. 1999;64(1):30-4.

74. Uemura ST, Gondo S, Haik L, Wanderley MT, Bussadori SK. Achondroplasia-case report. J Bras Odontopediatr Odontol Bebê. 2002;5(27):410-4.

75. Medeiros PFV, Dantas CMF, Ferreira IEL, Araújo HCA. Relação entre acondroplasia e obesidade: série de casos em um centro de referência em genética médica. RSC Online. 2017;6(3):117-25.

76. Medeiros PFV, Anjos ALB, Marquis VB. Complicações otorrinolaringológicas em pacientes com acondroplasia. XXXI Congresso Brasileiro de Genética Médica. 2019.
77. Hashmi SS, Gamble C, Hoover-Fong J, Alade AY, Pauli RM, Modaff P, Carney M, Brown C, Bober MB, Hecht JT. Multicenter study of mortality in achondroplasia. Am J Med Genet A. 2018;176(11):2359-64.

78. Hecht JT, Thompson NM, Weir T, Patchell L, Horton WA. Cognitive and motor skills in achondroplastic infants: neurologic and respiratory correlates. Am J Med Genet. 1991;41:208-11.

79. Todorov AB, Scott CI, Warren AE, Leeper JD. Developmental screening tests in achondroplastic children. Am J Med Genet. 1981;9:19-23.

80. Tunkel D, Alade Y, Kerbavaz R, Smith B, Rose-Hardison D, HooverFong J. Hearing loss in skeletal dysplasia patients. Am J Med Genet A. 2012;158A:1551-5.

81. Schkrohowsky JG, Hoernschemeyer DG, Carson BS, Ain MC. Early presentation of spinal stenosis in achondroplasia. J Pediatr Orthop. 2007;27:119-22.

\section{Publisher's Note}

Springer Nature remains neutral with regard to jurisdictional claims in published maps and institutional affiliations.
Ready to submit your research? Choose BMC and benefit from:

- fast, convenient online submission

- thorough peer review by experienced researchers in your field

- rapid publication on acceptance

- support for research data, including large and complex data types

- gold Open Access which fosters wider collaboration and increased citations

- maximum visibility for your research: over $100 \mathrm{M}$ website views per year

At BMC, research is always in progress.

Learn more biomedcentral.com/submissions 